\title{
Six Puzzles for Professor Akhil Amar
}

\author{
Seth Barrett Tillman ${ }^{* * *}$
}

Puzzle 1. Does "Officer," as used in the Succession Clause, Encompass Legislative Officers?

Puzzle 2. Does Impeachment Extend to Former "Officers"?

Puzzle 3. Who are the "Officers of the United States"?

Puzzle 4. Is the President an "Officer of the United States"?

Puzzle 5. Is the Presidency an "Office ... under the United States"?

Puzzle 6. Is "Officer of the United States" Coextensive with "Office under the United States"?

Dear Professor Amar,

Here are six constitutional puzzles for your consideration. I would be very pleased if you would respond, but I do not expect you to do so. I am sure you are very busy. Still, many, many people have read your books and articles, and heard your lectures and podcasts. And some of them are almost as smart and prolific (at least, collectively) as you are. So, even if you will not, perhaps, one or more of your many colleagues and students, readers and listeners would like to respond to one or more of these challenges.

\section{Puzzle 1.Does “Officer," as used in the Succession Clause, ${ }^{1}$ Encompass Legislative Officers?}

Your position is that legislative officer succession is unconstitutional. For example, in 1995, you wrote: "Legislators are not 'Officers' under the Succession Clause." 2 You repeated, clarified, and expanded on that claim in 2003 Senate testimony, where you stated: "House

\footnotetext{
** Lecturer of Law, National University of Ireland Maynooth. Preferred citation format: Seth Barrett Tillman, Six Puzzles for Professor Akhil Amar, Fourth Annual Constitutional Law Colloquium (Loyola University of Chicago November 1, 2013) (http://www.luc.edu/media/lucedu/law/conlawcolloquium/tillman.pdf); Northwestern University School of Law Workshop (November 5, 2013); University of Chicago Legal Scholarship Workshop (November 11, 2013); and National University of Ireland Maynooth Legal Studies Research Paper Series No. 2013-17-03, http://ssrn.com/abstract=2173899, works.bepress.com/seth_barrett_tillman/349/, http://works.bepress.com/seth_barrett_tillman/366/ (citation list and download counts only - currently over 500 downloads). I thank Robert Natelson and others for commenting on drafts of this paper. All errors remain mine. Citations, comments, and correspondence are always welcomed: sbarrettillman (at) yahoo.com.

${ }^{1}$ See U.S. Const. art. II, $\S 6$ (Succession Clause: "Congress may by Law provide for the Case of Removal, Death, Resignation or Inability, both of the President and Vice President, declaring what Officer shall then act as President, and such Officer shall act accordingly, until the Disability be removed, or a President shall be elected." (emphasis added)).

${ }^{2}$ Akhil Reed Amar \& Vikram David Amar, Is the Presidential Succession Law Constitutional?, 48 STAN. L. REV. 113, 136 (1995).
} 


\section{SETH BARRETT TILLMAN \\ SIX PUZZLES FOR PROFESSOR AKHIL AMAR DRAFT FOR SUBMISSION PURPOSES ONLY \\ 20/10/2013 7:19 AM}

and Senate leaders [as opposed to mere members] are not 'officers' within the meaning of the Succession Clause. Rather, the Framers clearly contemplated that a Cabinet officer would be named as Acting President."3

A year later, you again gave Senate testimony. But, on that occasion, you took the position that, in at least some circumstances, legislative officer succession was constitutional.

And I do think in very, very highly unusual situations where you really try to have Cabinet succession, [that is] [executive] officer succession, and everyone's gone, I think only a real constitutional zealot, maybe without good judgment, would say you can't have congressional leaders in that circumstance because the Constitution really isn't a suicide pact, and so I think I appreciate sort of the prudence involved [in the proposed amendments to the succession statute]. ${ }^{4}$

I do not have any problem with your changing your position. My problem is that you changed your mind yet again - and returned to your pre-2004 position. In a 2010 article, you wrote: "Article II empowers Congress to choose which Cabinet position is next in line, but it does not empower Congress to choose one of its own members ...." And in your 2012 book, you wrote: "[T]he current presidential-succession statute violates ... the letter of the original Constitution. . . . A member of the Congress, such as the House speaker, is simply [!] not an eligible 'Officer' within the meaning of the succession clause, which was designed to enable cabinet officers, not congressmen, to step up to fill the breach." 6

${ }^{3}$ Ensuring the Continuity of the United States Government - The Presidency: Joint Hearing before the S. Comm. on the Judiciary and Committee on Rules and Administration, 108th Cong. 7 (2003) (statement of Akhil Reed Amar, Southmayd Professor of Law and Political Science, Yale Law School) (emphasis added).

${ }^{4}$ Presidential Succession Act: Hearing Before the Subcomm. on the Const. of the H. Comm. on the Judiciary, 108th Cong. 52 (2004) (statement of Akhil Reed Amar, Southmayd Professor of Law and Political Science, Yale Law School).

${ }^{5}$ Akhil Reed Amar, Applications and Implications of the Twenty-Fifth Amendment, 47 Hous. L. REV. 1, 23 (2010) (emphasis added).

${ }^{6}$ AKHIL REED AMAR, AMERICA's UnwritTEN CONSTITUTION 404 (2012) (emphasis added); supra note 3, and accompanying text (asserting that the "Framers clearly contemplated" cabinet succession). But cf. UNWRITTEN, supra at 324-25 (denominating the cabinet as "a new entity," not contemplated in 1787 by the Framers and ratifiers, and not expressly described in the Constitution, but arising from practices starting with President Washington). The Framers "clearly contemplated" cabinet succession in 1787, but the cabinet did not come about until 1789? How is this "clear"? See Edward S. CORWIN, THE PREsident: OfFICE AND POWERS 1787-1957, at 4 (rev. 4th ed. 1957) ("The fact is that what the Framers had in mind was not the cabinet system, as yet nonexistent even in Great Britain ...."). Compare, e.g., Amar \& Amar, supra note 2, at 124 ("[T]he Constitution[] fundamental[ly] reject[s] . . a parliamentary system in which the legislature, or its dominant party, elects its own leader as Prime Minister/Chief Executive Officer." (emphasis added)), with AKHIL REED AMAR, AMERICA's CONSTITUTION: A BIOGRAPHY 153 (2005) (noting, in a sentence somewhat obscured by surrounding parentheses, that in 1787, "[t]he modern Westminster model, in which Parliament picks its own leader with minimal monarchical involvement, still lay in the future" (emphasis added)), Jack N. Rakove, Statement on the Background and History of Impeachment, 67 GEO. WASH. L. REV. 682, 688 (1999) ("[I]n fact, a full-blown model of parliamentary government was not yet available for the Framers to reject." (emphasis added)), and James A. Thomson, Executive Power, Scope and Limitations: Some Notes From a Comparative Perspective, 62 TEX. L. REV. 559, 569 (1983) (reviewing GeORge Winterton, PARLIAMENT, The 


\section{SETH BARRETT TILLMAN \\ SIX PUZZLES FOR PROFESSOR AKHIL AMAR \\ DRAFT FOR SUBMISSION PURPOSES ONLY \\ 20/10/2013 7:19 AM}

Again, your recent statements do not appear to be nuanced or to make any exception for unusual circumstances. And what situations involving presidential and vice presidential double vacancy are not unusual? Your most recent pronouncements appear to state a clear rule: members and legislative officers are not eligible to succeed to the presidency under the Succession Clause. There does not seem to be any obvious way to reconcile your pre-2004 position, with your 2004 position, and with your current position.

So exactly what is your position?

\section{Puzzle 2. Does Impeachment Extend to Former "Officers"?}

The Presidential Succession Clause uses the language of Officer. ${ }^{7}$ You have described former officers as non-officers, i.e., private citizens. As such, you have taken the position that a Speaker or Senate President Pro Tempore cannot resign his legislative position after succeeding to the presidency. In other words, only current officers are eligible to succeed under the Succession Clause, and if an officer resigns his (first-in-time) position after succeeding to the (acting) presidency, the (former) officer loses the ability to retain the (acting) presidency. ${ }^{8}$

However, the Impeachment Clause also uses the language of Office and Officer. ${ }^{9}$ But here, you do not suggest that only current officers may be impeached; rather, you suggest that even former officers may be impeached. ${ }^{10}$

Why the (atextual) distinction? The language of the Impeachment Clause extends to "civil officers of the United States." 11 In other words, modifiers immediately precede and follow "officers" in the Impeachment Clause. But, the Succession Clause extends to "Officers,"

EXECUTIVE AND THE GOVERNOR-GENERAL (1983)) ("In 1787 the principle of ministerial or executive responsibility to the House of Commons had not developed ....”).

${ }^{7}$ See supra note 1.

${ }^{8}$ See Amar \& Amar, supra note 2, at 120 ("[T] he moment an officer resigns, he becomes a mere citizen and is thus ineligible to succeed to or remain in the Oval Office [under any succession statute]."); see also Akhil Reed Amar, A Few Thoughts on Constitutionalism, Textualism, and Populism, 65 FordHAM L. REV. 1657, 1660 (1997) ("If Newt Gingrich is an officer because he is Speaker of the House, were he to take up the presidency, he would have to step down from the speakership. But then he would no longer be the officer that was the basis for his ascension. Now, that's because of a clause of the Constitution - the Incompatibility Clause - and the deep structure behind it."); cf. AMAR, BIOGRAPHY, supra note 6, at 171 ("Yet once [the Senate President Pro Tempore or Speaker] resigned [guided by separation of powers concerns], the ex-legislative leader would no longer even be a congressional "officer."').

${ }^{9}$ See U.S. CONST. art. II, § 4 (Impeachment Clause: "The President, Vice President and all civil Officers of the United States, shall be removed from Office on Impeachment for, and Conviction of, Treason, Bribery, or other high Crimes and Misdemeanors." (emphasis added)).

${ }^{10}$ See AMAR, UNWRITTEN, supra note 6, at 573 n.5 (explaining that "former officers are also arguably subject to impeachment"); AMAR, BIOGRAPHY, supra note 6, at 568 n.53 (same); Akhil Reed Amar, Attainder and Amendment 2: Romer's Rightness, 95 MICH. L. REV. 203, 214 n.36 (1996) (same).

${ }^{11}$ See U.S. CONST. art. II, $§ 4$ (emphasis added); infra note 32-33, and accompanying text. 


\section{SETH BARRETT TILLMAN \\ SIX PUZZLES FOR PROFESSOR AKHIL AMAR DRAFT FOR SUBMISSION PURPOSES ONLY \\ 20/10/2013 7:19 AM}

without these or any other restrictive modifying terms. Thus, textually, the office-related terminology in the Succession Clause has at least an equal if not a substantially wider scope than the cognate terminology in the Impeachment Clause. ${ }^{12}$ Yet, you take the position that the office-language in the Impeachment Clause has the wider scope (i.e., it reaches even former officers). Why?

I suppose you could argue that the office-language in the two clauses has equal temporal scope: the equal temporal scope position would be consistent with some of your prior writings. ${ }^{13}$ But, if that were your position, then both clauses should reach former officers (or neither clause should reach former officers).

How is your position consistent with the Constitution's text?

\section{Puzzle 3. Who are the "Officers of the United States"?}

Your position is that: "'Officers' of or under the United States ... means certain members of the Executive and Judicial Branches, but not legislators - the legacy of an earlier view sharply distinguishing the 'people's' representatives in Parliament from 'crown' officers in executive and judicial positions." ${ }^{14}$ Generally, I agree with that. ${ }^{15}$ But, on another occasion,

\footnotetext{
${ }^{12}$ See Amar \& Amar, supra note 2, at 114-15 (embracing civil/military distinction in the Constitution's Office-related terminology); see also AMAR, UNWRITTEN, supra note 6, at $577 \mathrm{n} .17$ (explaining that members of "the [federal] military chain of command [are] remove[d] ... from the category of 'civil' officers [as used in the Impeachment Clause]").

${ }^{13}$ See Amar \& Amar, supra note 2 passim (arguing that Officer in the Succession Clause is coextensive with Officers of the United States as used in the Appointments Clause and elsewhere in the Constitution); Amar, supra note 5, at 23 ("In the Constitution, 'officers' generally means executive and judicial officials, not legislators."). But see generally Allan Erbsen, Constitutional Spaces, 95 MinN. L. REV. 1168, 1188 \& nn.67-69 (2011) (noting textual distinction between officers of and under the United States).

${ }^{14}$ Amar \& Amar, supra note 2, at 115 (emphasis added); id. at 114-15 ("As a textual matter, each of these five [!] formulations seemingly describes the same stations (apart from the civil/military distinction) - the modifying terms 'of,' 'under,' and 'under the Authority of' are essentially synonymous." (emphasis added)); id. at 115-16 ("Thus, federal legislators are neither 'Officers under the United States,' nor (to the extent that there is any difference) 'Officers of the United States."' (emphasis added)); id. at 117 \& n.28 (arguing that the Constitution embodies a "global officer/legislator distinction"); see also AMAR, BIOGRAPHY, supra note 6, at 171 (denominating "officer[s] of the United States" as a "constitutional term of art reserved for members of the executive and judicial branches"). But $c f$. CASES OF CONTROVERTED ELECTIONS, DETERMINED IN COMMITTEES OF THE HOUSE OF COMMONS, IN THE SECOND PARLIAMENT OF THE REIGN OF QUEEN VICTORIA 59192 (Thomas Falconer \& Edward H. Fitzherbert eds., London, Saunders \& Benning 1839) (reproducing committee debate from disputed Galway election of 1838, where Mr. Austin-counsel for the sitting member who prevailed-distinguished offices "from the Crown" from offices "under the Crown" and cited statutes from the reign of Queen Anne, George III, and William IV (emphasis added)); GERARD CARNEY, MEMBERS OF PARLIAMENT: LAW \& ETHICS 67 (2000) (reporting judicial authority distinguishing "office of profit from the crown" from "office of profit under the crown" (emphasis added)); John Waugh, Disqualification of Members of Parliament in Victoria, 31 MONASH U. L. REV. 288, 297 (2005) (noting that English law distinguished "office of profit from the crown" from "office of profit under the crown" (emphasis added)); Parliamentary Elections: Who Can Be
} 


\section{SETH BARRETT TILLMAN \\ SIX PUZZLES FOR PROFESSOR AKHIL AMAR DRAFT FOR SUBMISSION PURPOSES ONLY 20/10/2013 7:19 AM}

you wrote: "[I]t should be noted that if Philadelphia II delegates [to a national convention to amend the Constitution] can be considered 'officers of the United States'-and it is not implausible to view them as such-Congress has an explicit textual mandate [under the Necessary and Proper Clause] to implement the Convention's effort to lay its proposal before the People." ${ }^{, 16}$ Not implausible?

Functionally, an Article $\mathrm{V}$ convention for proposing amendments ${ }^{17}$ is neither part of the Executive Branch nor part of the Judicial Branch. The participants in an Article V convention are customarily described as delegates ${ }^{18}$ or members $;{ }^{19}$ this is the same designation given to those elected to a legislature. Likewise, the work-product of an Article V convention seems akin - at least to my sensibilities - to that of a legislature. I grant you that Article V convention members might be entirely outside of the tripartite scheme that forms the regular government of the United States, but that it is just another way of saying that such members remain firmly outside the ambit of the Executive Branch and the Judicial Branch. Hence, they are not Officers of the United States.

Elected, 33 LAW Notes 10, 11 (1929) (same, and noting that the distinction goes back to the Succession to the Crown Act 1707).

${ }^{15}$ An alternative view is that the distinction you put forward (i.e., the "global" member-officer distinction) is merely an exemplar of the higher order structural division embodied in the constitutional text between: on the one hand, constitutionally mandated officials (i.e., elected positions or those individually or collectively presiding over departments or branches of the government of the United States, persons also colloquially known as magistrates or holders of a public trust under the United States), and, on the other hand, appointed or statutory offices (i.e., offices created, regularized, or defeasible by Congress, including both Officers of the United States and legislative officers chosen by either house of Congress, such as the Secretary of the Senate and the Clerk of the House, collectively the Officers ... under the United States).

${ }^{16}$ Akhil Reed Amar, Philadelphia Revisited: Amending the Constitution Outside Article V, 55 U. CHI. L. REV. 1043, 1061 n.67 (1988) (emphasis added). To be clear, Professor Amar is not speaking here directly to proper Article V conventions. Rather, he is speaking to an Article V analogue which would act outside the textual boundaries of the written Constitution. But in terms of the issue at hand: whether a member of an Article V convention or an Article V analogue is, or is not, an "officer of the United States," the two entities would appear to be the same in every way that matters for this discussion.

${ }^{17}$ State (as opposed to national) conventions ratifying or rejecting proposed constitutional amendments may require a different analysis, as these institutions are limited to up-and-down votes on national proposals. By contrast, members of Article $\mathrm{V}$ conventions (like members of traditional legislatures) have a substantially wider field in which to exercise their discretion. See generally U.S. CONST. art. V.

${ }^{18}$ See, e.g., AMAR, BIOGRAPHY, supra note 6, at 291 (using "delegate" language in relation to an Article V convention); Amar, supra note 16, at 1050 (using "delegate" language to describe members of the Philadelphia convention); see also, e.g., Robert G. Natelson, James Madison and the Constitution's "Convention for Proposing Amendments," 45 AKRON L. REV. 431, 440 (2012) ("An interstate convention consisted of delegations ('committees') from each state, made up of delegates or 'commissioners."').

${ }^{19}$ See, e.g., Akhil Reed Amar, The Consent of the Governed: Constitutional Amendment Outside Article V, 94 Colum. L. REv. 457, 494 \& n.147 (1994) (quoting Framing-era debate using the language of "member" to describe James Wilson's participation in the Philadelphia Convention). 


\section{SETH BARRETT TILLMAN \\ SIX PUZZLES FOR PROFESSOR AKHIL AMAR DRAFT FOR SUBMISSION PURPOSES ONLY

Indeed, it seems to me that the position held by an Article $\mathrm{V}$ convention member cannot be properly characterized even as an "office," much less an "office of the United States." In United States v. Hartwell, the Supreme Court explained: "An office is a public station, or employment, conferred by the appointment of government. The term embraces the ideas of [1] tenure, [2] duration, [3] emolument, and [4] duties.."20

Duration. The position of Article V delegate lacks duration: the position itself ceases once the convention's business ends.

Emolument. No federal statute grants the position of Article V delegate any emoluments. $^{21}$

Duties. An Article V delegate has only a single duty (to propose amendments ${ }^{22}$ ), as opposed to multiple duties (as required by Hartwell ${ }^{23}$ ).

Tenure. On the one hand, delegates to the Congress of the Articles of Confederation $^{24}$ and to the Philadelphia Convention in 1787 lacked tenure: they could be recalled by the legislature which selected them. Should a future Article V convention follow historical practices, and should future Article V convention members be chosen by state legislatures, it would seem to follow that such delegates would also lack tenure.

Appointment of Government. On the other hand, if Article $\mathrm{V}$ delegates are not appointed $^{25}$ by the state legislatures, if, instead, delegates are elected ${ }^{26}$ directly by the People, then the position of delegate is not one "conferred by the appointment of government," 27 and, hence, the position of delegate is not an "office" at all. If the position of Article V delegate is not an office, then it stands to reason that it is not an office of or under the United States.

\footnotetext{
${ }^{20}$ United States v. Hartwell, 73 U.S. 385, 393 (1867) (Swayne, J.) (emphasis and underscore added).

${ }^{21}$ Cf. Satrucharla Chandrasekhar Raju v. Vyricherla Pradeep Kumar Dev, A.I.R. 1992 S.C. 1959, para. 7 (India) (Reddy, J.) (explaining that in determining whether a position is an office of profit under the government of India, the court examines, among other factors, if the post is "paid out of the revenues of [the] Government of India" (emphasis added)).

${ }^{22}$ Cf. AMAR, BIOGRAPHY, supra note 6, at 290 ("Article V made clear that if and when summoned into existence, [a] federal convention could merely propose amendments . . .." (emphasis added)).

${ }^{23}$ See supra note 20 , and accompanying text.

${ }^{24}$ See, e.g., ARTICles OF CONFEDERATION of 1781, art. V, cl. 1 ("For the most convenient management of the general interests of the United States, delegates shall be annually appointed in such manner as the legislatures of each State shall direct, to meet in Congress on the first Monday in November, in every year, with a power reserved to each State to recall its delegates, or any of them, at any time within the year, and to send others in their stead for the remainder of the year." (emphasis added)).

${ }^{25}$ The Constitution of 1787 distinguishes appointment and election. See, e.g., U.S. ConsT. art. II, $\S 6, \mathrm{cl} .2$ ("No Senator or Representative shall, during the Time for which he was elected, be appointed to any civil Office under the Authority of the United States, which shall have been created, or the Emoluments whereof shall have been increased during such time...." (emphasis added)); infra note 33 (quoting Justice Story and Attorney General Reverdy Johnson).

${ }^{26} I d$.

${ }^{27}$ Hartwell, 73 U.S. at 393 (emphasis added).
} 


\section{SETH BARRETT TILLMAN \\ SIX PUZZLES FOR PROFESSOR AKHIL AMAR \\ DRAFT FOR SUBMISSION PURPOSES ONLY \\ 20/10/2013 7:19 AM}

Do you continue to maintain that Article V convention delegates are Officers of the United States?

\section{Puzzle 4. Is the President an "Officer of the United States"?}

Your position is that an acting President is an "officer of the United States" because he or she "wield[s] the full and awesome executive power of the United States ...." So, it follows you believe that an elected President is also an "Officer of the United States." 29 The problem is that the text of the Constitution does not actually say that. At best, your position is an inference. $^{30}$

But you do not support this inference, and many other modern authorities-including the federal courts - have contested it. ${ }^{31}$ Early authorities have also contested it. For example, the Impeachment Clause states: "The President, Vice President and all civil Officers of the United States, shall be removed from Office on Impeachment for, and Conviction of, Treason, Bribery, or other high Crimes and Misdemeanors." 32 In his Commentaries on the Constitution, Justice Story noted that this clause does not say "and all other civil Officers of the United States." ${ }^{33}$ In reliance on this textual omission, Story concluded that the President

\footnotetext{
${ }^{28}$ Amar \& Amar, supra note 2, at 136 n.143.

${ }^{29}$ Id. at $136 \mathrm{n} .143$; see also AMAR, BIOGRAPHY, supra note 6, at 171 ("This point was not textually explicit but structurally essential: No man could be entrusted, even temporarily, with authority to preside over both the legislature and the executive simultaneously." (emphasis added)).

${ }^{30}$ Compare, e.g., AMAR, UNWRITTEN, supra note 6, at 577 n.17 ("Under Article II, section 4, only 'civil Officers' are impeachable. (Presidents and vice presidents are also mentioned separately in this clause, perhaps, to blunt any argument that their role atop - or in the VP's case, potentially atop - the military chain of command removes them from the category of "civil' officers.)"), with Oliver P. Field, The Vice-Presidency of the United States, 56 AM. L. REV. 365, 382 (1922) ("Whether the president and vice-president are officers of the United States is a subject on which conflicting opinions are held."). But see infra note 41-42 (collecting counter-authority taking the position that elected officials, such as the President, are not officers of the United States).

${ }^{31}$ See, e.g., Free Enter. Fund v. Pub. Co. Accounting Oversight Bd., 130 S. Ct. 3138, 3155 (2010) (Roberts, C.J.) ("The people do not vote for the 'Officers of the United States.' Art. II, § 2, cl. 2."); Motions Sys. Corp. v. Bush, 437 F.3d 1356, 1372 (Fed. Cir. 2006) (Gajarsa, J., concurring in part and concurring in the en banc judgment) ("It is plain that the President is not an 'officer of the United States' for Appointments Clause, Commission Clause, or Oath of Office Clause purposes." (emphasis added, emphasis in the original omitted)); RUTH C. SiLVA, PRESIDENTIAL SuCCESSION 149 (1951) ("'Officers of the United States' are not appointed by electoral colleges. They are appointed by the President and Senate, by the President alone, by the department heads, or by the courts of law." (emphasis added)); Ruth C. Silva, The Presidential Succession Act of 1947, 47 MicH. L. Rev. 451, 475 (1949) ("'Officers of the United States' are appointed by the President and the Senate, by the President alone, by the department heads, or by the courts. Officers in the constitutional sense are not elected by the electoral colleges." (emphasis added)).

${ }^{32}$ U.S. CONST. art. II, $\S 4$ (emphasis added).

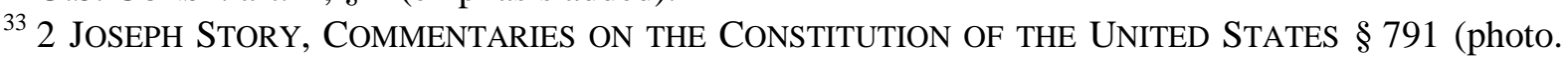
reprint 1999) (1833) (emphasis added); $i d$. (stating affirmatively that "the language of the [Impeachment] [C]lause ... . lead[s] to the conclusion, that they [the President and the Vice President] were enumerated, as contradistinguished from, rather than as included in the description of, civil officers of the United States" (emphasis added)); see also CONG. GLOBE, 38TH CONG., 1ST SESS. 291
} 


\section{SETH BARRETT TILLMAN \\ SIX PUZZLES FOR PROFESSOR AKHIL AMAR DRAFT FOR SUBMISSION PURPOSES ONLY 20/10/2013 7:19 AM}

and Vice President are not encompassed by the Constitution's civil officers of the United States-language.

Admittedly, the absence of the word "other" from the opening phrase of the Impeachment Clause is only some evidence, not conclusive evidence, for Story's position. But, please, keep in mind that there is good scholarly authority for Story's text-reliant interpretation, i.e., the absence of the word "other" from a constitutional provision is meaningful. That scholarly authority would be you. ${ }^{34}$ Still, the text is, arguably, ambiguous. In such circumstances, when confronted with ambiguous text, it is customary to turn to legislative or drafting history. ${ }^{35} \mathrm{In}$ fact, in early drafts of the Impeachment Clause, the word "other" immediately preceded "civil Officers, "36 but it was removed by the Committee of Style. ${ }^{37}$ Thus, the absence of the word "other" from the final draft does not appear to be accident or happenstance. It is not that the

(Washington, John C. Rives Jan. 22, 1864) (reporting January 21, 1864 speech by former Attorney General and then Senator Reverdy Johnson: "Why were the President and Vice President included in th[e] [I]mpeach[ment] [C]lause? What was the necessity for it? If it be true that they were civil officers, why would it not have been sufficient to say, 'All civil officers of the United States?' Can any other reason be given ... [than] that it was because the Convention did not esteem the President and Vice President civil officers; but intended by the term 'civil officers,' as here found, to exclude all who are not appointed officers under the Constitution; and because the President of the United States is elected by the people, and the Vice President is elected by the people, and it was desirable, upon grounds of public policy, to subject them to the impeaching powers of Congress, they are inserted; but the insertio unius est exclusio alterius is a familiar rule of interpretation. Their insertion demonstrates that in the intendment of the Convention they were not civil officers ...." (emphasis added)). Do not you frequently turn to this canon of construction? See, e.g., Akhil Reed Amar, Of Sovereignty and Federalism, 96 YALE L.J. 1425, 1449 (1987) (denominating expressio unius est exclusio alterius as a "well-established rule of construction").

${ }^{34}$ Article V, Clause 2 of the Articles of Confederation states: "[N]or shall any person, being a delegate, be capable of holding any office under the United States, for which he, or another for his benefit, receives any salary, fees or emolument of any kind." ARTICLES OF CONFEDERATION of 1781, art. V, cl. 2 (emphasis added). In a discussion of this provision, you wrote: "[This provision states 'any office,'] [n]ot 'any other,' suggesting that congressional delegates were state officers." Amar, supra note 33, at 1447 n.87 (emphasis added). But cf., e.g., AMAR, UNWRITTEN, supra note 6, at $75 \mathrm{n}$.* ("We cannot always determine which textual omissions were pointed and purposeful ...."). Of course, even the best scholars change their mind from time to time.

${ }^{35}$ See, e.g., Akhil Reed Amar, The Supreme Court, 1999 Term - Foreword: The Document and the Doctrine, 114 HARV. L. REV. 26, 47 n.65 (2000) ("Details of legislative history invisible to ratifiers and later generations of ordinary Americans should never trump the text itself, though drafting history can at times help highlight certain features of the text.").

362 THE RECORDS OF THE FEDERAL CONVENTION OF 1787, at 552 (Max Farrand ed., 1911) [hereinafter FARRAND'S RECORDS] ("On motion [on September 8, 1787] 'The [V]ice-President and other Civil officers of the U. S. shall be removed form office on impeachment and conviction as aforesaid' was added to the clause on the subject of impeachments [which until then had only extended to the President]." (emphasis added)); id. at 545 (same, and noting unanimous passage).

${ }^{37}$ See id. at 600 (dropping "other" in the Impeachment Clause from the Committee of Style's draft constitution). 


\section{SETH BARRETT TILLMAN \\ SIX PUZZLES FOR PROFESSOR AKHIL AMAR DRAFT FOR SUBMISSION PURPOSES ONLY \\ 20/10/2013 7:19 AM}

Framers forgot to put "other" in the draft Constitution; rather, they took it out. This appears to be a choice: nothing could have been simpler than leaving well enough alone. ${ }^{38}$

In regard to the Impeachment Clause, you recently wrote that:

Under Article II, section 4, only "civil Officers" are impeachable. (Presidents and vice presidents are also mentioned separately in this clause, perhaps, to blunt any argument that their role atop - or in the VP's case, potentially atop - the military chain of command removes them from the category of 'civil' officers. $)^{39}$

Do you think Story's interpretation of the Impeachment Clause is incorrect? (You would not be the first to think Story in error. $\left.{ }^{40}\right)$ Story's position has the virtue of cohering with the text. By contrast, your position is substantially under inclusive. Under your interpretation, the Framers, in addition to listing the President and Vice President, should have also included statutory successors under the Succession Clause. But, they did not do so. Is not that a good reason to prefer Story's interpretation of the clause over your own?

Between these two views, Story's and your own, would you not concede that Story's view is, at the very least, within the ambit of reasonable opinion? Certainly many commentators have

\footnotetext{
${ }^{38}$ For somewhat similar reasoning, see Akhil, Reed Amar, A Neo-Federalist View of Article III: Separating the Two Tiers of Federal Jurisdiction, 65 B.U. L. REV. 205, 242-43 (1985) ("The draft constitution produced by the Committee of Style omitted the word 'all' in the clause setting out the Supreme Court's original jurisdiction. That one word ['all'] was thereafter specifically inserted by the Convention during the last days at Philadelphia." (emphasis added)). Your use of "specifically" seems somewhat overly strong, as you note in a footnote. See id. at 243 n.126 ("Unfortunately, the decisions to make this [change adding 'all'] and several other stylistic changes are nowhere recorded in the Convention Journal or Madison's notes. There is thus no surviving evidence concerning the date of the change, or the discussion and votes surrounding it. Presumably, however, the one-word change was made deliberately and self-consciously; to presume otherwise is to impute capriciousness to the Convention."); Akhil Reed Amar, Marbury, Section 13, and the Original Jurisdiction of the Supreme Court, 56 U. CHI. L. REV. 443, 480 (1989) ("The carefully selective use of the word 'all' in the Article III jurisdictional menu should make us specially sensitive to its use - and nonuse-later in that Article. Records of the Philadelphia Convention confirm the care with which the word 'all' was used by the framers in Article III. A penultimate draft Constitution authored by the Committee of Style had omitted the word 'all' from the enumeration of Supreme Court original jurisdiction; that one word was later added before the word 'cases,' which modifies the Ambassador Clause, but not before the words 'those in which a state shall be party." (footnote omitted)).

${ }^{39}$ AMAR, UNWRITTEN, supra note 6, at 577 n.17.

${ }^{40}$ Cf. Steven G. Calabresi, Closing Statement, A Term of Art or the Artful Reading of Terms?, in Seth Barrett Tillman \& Steven G. Calabresi, Debate, The Great Divorce: The Current Understanding of Separation of Powers and the Original Meaning of the Incompatibility Clause, 157 U. PA. L. REV. PENNUMBRA 134, 155 (2008) (denominating Story's position as too "erudite"!). How Professor Calabresi arrived at the conclusion that Story was too "erudite" is a wholly separate puzzle. See also infra note 44 (quoting Professor Prakash). You have frequently quoted Justice Story and his Commentaries favourably. See, e.g., Akhil Reed Amar, Some New World Lessons for the Old World, 58 U. CHI. L. REV. 483, 490 (1991) (denominating Story's Commentaries as "the most important and insightful nineteenth-century ... treatise"); Amar, supra note 19, at 483 (denominating Story's Commentaries as "landmark," and Joseph Story as "the great Associate Justice"). Have you ever cited Story's position as anything other than reliable? Is there any good reason to start here?
} 


\section{SETH BARRETT TILLMAN \\ SIX PUZZLES FOR PROFESSOR AKHIL AMAR DRAFT FOR SUBMISSION PURPOSES ONLY \\ 20/10/2013 7:19 AM}

adopted Story's position ${ }^{41}$ or one akin to it. ${ }^{42}$ Where a constitutional provision is subject to two reasonable interpretations, one traditionally turns to practice. Consider the Commissions Clause. Article II, Section 3 of the Constitution provides: "[The President] .. shall Commission all the Officers of the United States." All means all. ${ }^{43}$ The undisputed fact of the matter is that Presidents - starting with George Washington-have neither commissioned themselves (and their vice presidents), nor have they commissioned their successors (and their successors' vice presidents). ${ }^{44}$ Is not practice under the Commissions Clause a reliable historical gloss in regard to the meaning of "Officers of the United States"? ${ }^{45}$

${ }^{41}$ See, e.g., CONGRESSIONAL RECORD: CONTAINING THE PROCEEDINGS OF THE SENATE SITTING FOR THE TRIAL OF William W. Belknap, LATE SECRETARY OF WAR, ON THE ARTiCles OF IMPEACHMENT EXHIBITED BY THE HOUSE OF REPRESENTATIVES 145 (Washington, Government Printing Office 1876) (Senator Newton Booth, from California, stating, on May 27, 1876, "[Justice] Story very ably argues, and refers to this very section of the Constitution in confirmation, that the President is not an officer of the United States. As was tersely said by the Senator from Massachusetts, [Mr. BouTwELL,] 'He is part of the Government."'); id. at 130 (Senator George Sewell Boutwell stating, on May 27, 1876, "[F]or according to the Constitution, as well as upon the judgment of eminent commentators, the President and Vice-President are not civil officers"); 1 JOHN RANDOLPH TUCKER, THE CONSTITUTION OF THE UNITED STATES: A CRITICAL DisCUSSION OF ITS GENESIS, DEVELOPMENT, AND INTERPRETATION § 199(i), at 412-13 (Henry St. George Tucker ed., Chicago, Callaghan \& Company 1899) ("The language of the [Impeachment] [C]lause indicates that, in a constitutional sense, the President and Vice-President are not civil officers of the United States, for otherwise the language would have been 'and other civil officers."').

${ }^{42}$ See, e.g., Memorandum from Morton Rosenberg, Legislative Attorney, Re: Applicability of the Emoluments Clause (Article I, Section 6, Clause 2) of the Constitution to the Office of VicePresident, at *CRS-7 (circa Oct. 1973) ("[T] he constitutional term 'civil office' was meant to include only those offices which are created by Congress and subject to appointment, and not those elective offices established by the Constitution itself." (emphasis in the original)); Charles Pergler, Note, Trial of Good Behavior of Federal Judges, 29 VA. L. REV. 876, 879 (1943) ("The President and Vice President, being elective functionaries, are not 'civil officers of the United States' within the meaning of Article II, Section 4."); cf., e.g., Proceedings of Congress.; Senate. From Washington. House of Representatives., N.Y. TIMES, Jan. 26, 1864 (Senator Willard Saulsbury, Sr., of Delaware, on January 25, 1864, describing the United States Senate as a "body [which] was part of the Government, and not a body under the Government" (emphasis added)), available at http://tinyurl.com/7bd3aq6. See generally, e.g., Roy E. Brownell II, Can the President Recess Appoint a Vice President?, 42 PRES. STUD. Q. 622 passim (2012) (accepting the newly evolving consensus position: the Vice President is not an Officer of the United States).

${ }^{43}$ See AMAR, BIOGRAPHY, supra note 6, at 236 ("In the Article III vesting clause and roster, 'shall' and 'all' meant what they said."); Raoul Berger, Impeachment for "High Crimes and Misdemeanors," 44 S. CAL. L. REV. 395, 424 (1971) ("One who would make 'all' mean less than 'all' has the burden of proving why the ordinary meaning should not prevail." (citing Henry M. Hart, Jr., Book Review, 67 HARV. L. REV. 1456, 1465 (1954))); cf. Vasan Kesavan, Is the Electoral Count Act Unconstitutional?, 80 N.C. L. REV. 1653, 1792 (2002) ("The word 'every' . . means every and not some.").

${ }^{44}$ See, e.g., CASE OF Brigham H. Roberts, OF UtAh, H. ReP. No. 85, Pt. 1, 56th Cong., 1st Sess. 36 (1900) ("[The President] does not commission himself, nor does he commission the Vice President ....”); Memorandum from Morton Rosenberg, Legislative Attorney, Re: Applicability of the Emoluments Clause (Article I, Section 6, Clause 2) of the Constitution to the Office of VicePresident, at *CRS-10 (circa Oct. 1973) ("Of course, the Vice-President is not commissioned by the President and it is significant that under the Twenty-Fifth Amendment, the nomination and confirmation of a new Vice-President by both Houses of Congress is not followed by a 


\section{SETH BARRETT TILLMAN \\ SIX PUZZLES FOR PROFESSOR AKHIL AMAR DRAFT FOR SUBMISSION PURPOSES ONLY \\ 20/10/2013 7:19 AM}

Admittedly, it is true that Presidents and Vice Presidents receive official notification of their election from Congress and this notification is (arguably) a functional equivalent of a presidential commission. ${ }^{46}$ However, the language of the Commissions Clause makes no exceptions for officers who are in possession of commission-equivalents from Congress. If the presidency were an Officer of the United States, President George Washington should have issued commissions to himself and to Vice President John Adams (and, eight years later, to John Adams, as president-elect, and to Thomas Jefferson, as Vice President-elect). But, Washington did not do this. This is an unbroken continuous Executive Branch practice going back to the Founding era. Moreover, the other Branches have not contested this practice in any way. Surely, you agree that this long standing practice - going back to George Washington - "confirms" 47 that the President and Vice President are not Officers of the United States. $^{48}$

commissioning.”), available at http://works.bepress.com/seth_barrett_tillman/164/ (click "Rosenberg Memorandum"). Authority on this point is plentiful. But compare Saikrishna Bangalore Prakash, Response, Why the Incompatibility Clause Applies to the Office of President, 4 DUKE J. CONST. L. \& PUB. POL'Y 143, 147 (2009) ("That no physical evidence of such a commission [issued to a President or Vice President] exists, however, certainly does not prove that the President never issued one."), with Gary Lawson, Optimal Specificity in the Law of Separation of Powers: The Numerous Clauses Principle, 124 HARV. L. REV. F. 42, 47 (2011) ("It is a basic principle of epistemology that he who asserts the existence of something bears the burden of proof." (emphasis added)). Professor Prakash's position is yet another officer-related puzzle! Perhaps, the reader begins to sense a pattern? See also supra note 40 (quoting Professor Calabresi).

${ }^{45}$ See Akhil Reed Amar, The President, the Cabinet, and Independent Agencies, 5 U. ST. ThOMAS J.L. \& PUB. POL'Y 36, 39 (2010) ("Several of the basic features of America's enduring presidential system were established less by constitutional text, than by the gloss on the text provided by Washington's actions ...."); id. at 41 ("But the script [for Jefferson's 1803 Louisiana purchase] was established less by the debatable text of the written Constitution, than by the definitive gloss on that text that Washington had added in the early 1790s.").

${ }^{46}$ AMAR, UNWRITTEN, supra note 6, at 573 n.14 ("A new president-elect receives his official designation - his commission-equivalent-from Congress as a whole, which bears responsibility for counting electoral votes, resolving any disputes... and, if necessary, choosing among the top electoral-vote-getters ...."). Professors Amar's analogy—between a presidential commission and congressional notification - is not a precise one. Presidential commissions are impersonal records; congressional notification, by contrast, is in-person. Congress chooses members or agents to notify the President and Vice President of their election: such notification is in person. See, e.g., 1 JouRnAL OF THE SENATE OF THE United States OF AMERICA 8-9 (Washington, Gales \& Seaton 1820) (April 6, 1789 entry) (appointing Charles Thomson, former secretary of the Articles Congress, to notify George Washington of his election as President). In addition to in-person notification, the first President and Vice President also received "certificates of [their] election." Id. Such presidential and vice presidential certificates of election (issued by Congress) are akin to what senators and representatives receive from state elections authorities. If holding a certificate of election makes a person an Officer of the United States, then members of Congress would also be Officers of the United States.

${ }^{47}$ In assessing whether members and legislative officers are Officers of the United States, you have noted that these federal officials have never received presidential commissions and that this longstanding non-practice "confirms [your] reading" of the Commissions Clause. Amar \& Amar, supra note 2, at 115. Like members of Congress, Presidents and Vice Presidents have not 


\section{SETH BARRETT TILLMAN \\ SIX PUZZLES FOR PROFESSOR AKHIL AMAR \\ DRAFT FOR SUBMISSION PURPOSES ONLY \\ 20/10/2013 7:19 AM}

\section{Puzzle 5. Is the Presidency an "Office . . . under the United States"?}

You have written on any number of occasions that the Constitution's Office... under the United States language (and related cognate language) extends to the President. ${ }^{49}$ One such provision using this language is the Foreign Emoluments Clause, which states:

No Title of Nobility shall be granted by the United States: And no Person holding any Office of Profit or Trust under them, shall, without the Consent of the Congress, accept of any present, Emolument, Office, or Title, of any kind whatever, from any King, Prince, or foreign State. ${ }^{50}$

And you have taken the position that this clause applies to the President. ${ }^{51}$

You have also written that President George Washington's conduct deserves special deference, ${ }^{52}$ and that this deference is based on Washington's "scrupulous constitutional consciousness." ${ }^{, 53}$ Moreover, you have indicated that this heightened deference applies to how Washington "conducted foreign affairs" $" 54$ and to matters of "presidential etiquette.,"55

received presidential commissions. By a parity of reasoning, history and the Commissions Clause would seem to "confirm" that Presidents and Vice Presidents are not Officers of the United States.

${ }^{48} I d$.

${ }^{49}$ See, e.g., id. at 119 n.34 ("A quibbler might try to argue that the President does not, strictly speaking, 'hold[ ] . . . Office under the United States,' and is instead a sui generis figure. But ...."); see also, e.g., AMAR, BIOGRAPHY, supra note 6, at 131 (asserting that the Incompatibility Clause which uses Office under the United States language - "barred a sitting president from serving in Congress"); see also, e.g., id. at 171 ("The instant such a lawmaker became acting president, he would thereby 'hold[]' an 'Office under the United State' and thus be obliged by the incompatibility clause to quit Congress."); id. at 340-41, 452-53, 556-57, 598, and 625; cf. supra note 13; infra note 51 (quoting the Foreign Emoluments Clause which uses "Office ... under the United States" language).

${ }^{50}$ U.S. CONST. art. I, § 9, cl. 8.

${ }^{51}$ See AMAR, BIOGRAPHY, supra note 6, at 182 ("[T] barred all federal officers, from the president on down, from accepting any 'present' or 'Emolument' of 'any kind whatever' from a foreign government without special congressional consent." (emphasis added)). But see also infra note 66 (quoting McKnight's treatise); but cf. McGregor v. Balch, $14 \mathrm{Vt}$. 428 (1842) (Williams, Ch. J.) ("[W]e have no doubt that the office of postmaster is an ${ }^{\left[{ }^{[}\right]}$office ... of profit and trust ... under the authority of congress. ${ }^{[,]}$The office itself is created by act of congress, and all the regulations in relation thereto, are made and established under the same authority. So that the question [of the position of the postmaster] is so far divested of the doubt which has been sometimes entertained, whether other offices under the general government, for which no act or proceedings of congress were made or required, are or are not within the spirit or letter of the prohibition created by the [Incompatibility Clause in the Vermont] constitution." (emphasis added)); infra notes 101, 112 (collecting other state case law).

${ }^{52}$ See AMAR, BIOGRAPHY, supra note 6, at 470 ("I have paid special heed to the practices of President Washington."); AMAR, UNWRITTEN, supra note 6, at 332 ("To understand the full meaning of Article II over the course of American history, we must read its words through a special set of lenses - the spectacles of George Washington.").

${ }^{53}$ AMAR, UnWritTEN, supra note 6, at 314; Akhil Reed Amar, America's Constitution, Written and Unwritten, 57 SYR. L. REV. 267, 271 (2007) ("Certain basic features of America's constitutional system were established less by the Constitution's text than by President Washington's actions, which 


\section{SETH BARRETT TILLMAN \\ SIX PUZZLES FOR PROFESSOR AKHIL AMAR \\ DRAFT FOR SUBMISSION PURPOSES ONLY \\ 20/10/2013 7:19 AM}

It seems to me that your two positions - that the Foreign Emoluments Clause applies to the President, and that special deference is due Washington's conduct - do not cohere particularly well. George Washington, while President, received gifts both from LaFayette ${ }^{56}$ (while the latter was a French government official), and from the French ambassador to the United States. ${ }^{57}$ Washington accepted and kept the gifts. Likewise, Washington neither asked for nor received congressional consent. Were not these gifts matters of foreign affairs or, at the very least, presidential etiquette?

It strikes me that there are two possibilities. Either (A) Washington was correct (the scope of the Foreign Emoluments Clause does not reach the President), and you are incorrect (in suggesting that this clause reaches the presidency); or (B) Washington was incorrect, and you are correct. As a matter of original public meaning, you cannot both be correct: "The Constitution must mean something ....,"58

As to (A), there is some good reason to believe that Washington was correct. First, there is his own "scrupulous" conduct. Second, there is the fact that the public knew that LaFayette gave Washington the key to the Bastille, and no one complained about Washington's not having congressional consent. No one complained: no one in Congress; no one in the press; no one even in private correspondence (at least, as far as I know). Likewise, in 1792, the Senate issued a (purported) order directing the Secretary of the Treasury, Alexander Hamilton, to compile a report listing "every person holding any civil office or

he undertook with scrupulous constitutional consciousness and with the acquiescence of the other branches of government and the American people themselves.").

${ }^{54}$ Id. at 309-10 ("In the American constitutional tradition, what Washington did - the particular way in which he ... conducted foreign affairs ... - has often mattered much more than what the written Constitution says, at least in situations where the text is arguably ambiguous and Washington's actions fall within the range of plausible textual meaning.").

${ }^{55} \mathrm{Id}$. at 309 (noting that "the constitutional understandings that crystallized during the Washington administration have enjoyed special authority on a wide range of issues, especially those concerning ... presidential etiquette.”).

${ }^{56}$ See THE LETTERS OF LAFAYETTE TO WASHINGTON 1777-1799, at 347-48 (Louis Gottschalk ed., 1976) (reproducing March 17, 1790 letter from Lafayette to Washington giving the key to the Bastille).

${ }^{57}$ See Letter from Ambassador Ternant to George Washington (Dec. 22, 1791), in 9 THE PAPERS OF GeORGE WASHINGTON 306, 306 n.1 (Mark A. Mastromarino \& Jack D. Warren, Jr., eds., 2000) ("Permit me to present you with a new print of the king of the [F]rench-I shall feel a very great Satisfaction if you will consider that feeble mark of my lively and respectful attachment for your person, as worthy your kind acceptance." (emphasis added)); Letter from George Washington to Ambassador Ternant (Dec. 22, 1791), in id. at 306 ("I accept, with great pleasure, the new and elegant print of the King of the French, which you have been so obliging as to send to me this morning as a mark of your attachment to my person." (emphasis added)).

${ }^{58}$ Amar \& Amar, supra note 2, at 136 n.143 ("The Constitution must mean something - the best reading of the document either permits or bars legislative succession."); $c f$. Akhil Reed Amar, Taking Article III Seriously: A Reply to Professor Friedman, 85 Nw. U.L. REV. 442, 443 (1991) ("[T]he real question ... [is] which reading of [A]rticle III—all of which . . impose some limits—is the best?" (emphasis in the original)). 


\section{SETH BARRETT TILLMAN \\ SIX PUZZLES FOR PROFESSOR AKHIL AMAR DRAFT FOR SUBMISSION PURPOSES ONLY \\ 20/10/2013 7:19 AM}

employment under the United States"59 with their salaries. Every, not some; any, not some. Nine months later, Hamilton returned a ninety-page report. He omitted the President and Vice President, ${ }^{60}$ the highest and fourth highest paid federal officials. A fair-minded person might very well conclude that the collective Washington and Hamilton evidence establishes that the presidency is not an Office under the United States. Would you care to put forward any support, argument, or evidence defending (B) as the better view?

Perhaps, you think Washington and Hamilton erred? After all, Washington was only human. He signed the Judiciary Act of 1789, and the Supreme Court subsequently determined that that Act was unconstitutional. ${ }^{61}$ But that explanation will not do. Washington's error (if it was an error), in regard to signing the Judiciary Act, related to a technical legal issue. ${ }^{62}$ But, if he made an error in regard to these foreign gifts, it puts in doubt his personal honor and integrity, and his willingness to comply with the Constitution's express command, or it indicates that Washington lacked basic knowledge in regard to the Constitution's provisions (including those applying to his own office - the presidency). If you defend your position in regard to the original public meaning of the Foreign Emoluments Clause, you do so at Washington's expense, and then any legal theory or theories dependent on Washington and the Washington-era precedents must fall. If the Washington-era precedents are unreliable, then what (if anything) is left of your defense of the unitary executive thesis? ${ }^{63}$

There is good reason to believe that Congress shared Washington's and Hamilton's view. For example, in An Act for the Punishment of Certain Crimes against the United States, a 1790 statute of the First Congress, Congress disqualified certain convicts from holding any "office of honor, trust or profit under the United States." ${ }^{\text {, Th }}$ This statute's disqualification provision cannot extend to constitutionally-created offices, such as the President, Vice President, and members of Congress. ${ }^{65}$ Rather than presuming that Congress passed and the President

591 JOURNAL OF THE SENATE, supra note 46, at 441 (May 7, 1792 entry) (emphasis added).

${ }^{60}$ See AleXANDER Hamilton, Report on the Salaries, Fees, and Emoluments of Persons Holding Civil Office Under the United States (Feb. 26, 1793), in 14 THE PAPERS OF ALEXANDER HAMILTON 157, 157-59 (Harold C. Syrett \& Jacob E. Cooke eds., 1969). (For the reader who would like to explore the original Hamilton-authored document and its subsequent reproductions, see Seth Barrett Tillman, Hamilton, the Secretary of the Senate, and Jefferson (2011), http://works.bepress.com/seth_barrett_tillman/203/(click "Related Files").)

${ }^{61}$ See Marbury v. Madison, 5 U.S. (1 Cranch) 137 (1803) (Marshall, C.J.) (finding section 13 of the Judiciary Act of 1789 unconstitutional).

${ }^{62}$ See AMAR, BIOGRAPHY, supra note 6, at 211 (describing section 13 of the Judiciary Act of 1789 as a "technical issue of judicial procedure").

${ }^{63}$ See, e.g., AMAR, UnwritTEN, supra note 6, at 319-27 (defending the unitary theory of the executive based on precedents established by George Washington and his administration); see also, e.g., id. at 328-332 (embracing George Washington's position in regard to Senate "advice and consent").

${ }^{64}$ An Act for the Punishment of Certain Crimes against the United States, ch. 9, § 21, 1 Stat. 112, 117 (1790) (emphasis added); see also AMAR, BIOGRAPHY, supra note 6, at 222 (discussing this statute). For other examples of early federal statutes using this or similar language see Act of Sept. 2, 1789, ch. 12, § 8, 1 Stat. 65, 67; Act of July 31, 1789, ch. 5, § 35, 1 Stat. 29, 46; Act of Sept. 1, 1789, ch. 11, $\S 34,1$ Stat. 55, 64-65.

${ }^{65}$ See The FedERAlist No. 60, at 326 (Alexander Hamilton) (J.R. Pole ed., 2005) (noting that the qualifications for membership in Congress are "defined and fixed in the constitution; and are 


\section{SETH BARRETT TILLMAN \\ SIX PUZZLES FOR PROFESSOR AKHIL AMAR DRAFT FOR SUBMISSION PURPOSES ONLY \\ 20/10/2013 7:19 AM}

signed an unconstitutional statute, it makes considerably more sense to assume that this statute was constitutional. This statute was constitutional precisely because its office ... under the United States-language only reached statutory or appointed officers. And there is good reason to believe that these statutory drafting conventions did not vanish without a trace; rather, they continued to be understood more than a century later. ${ }^{66}$

What reason or evidence can you put forward in support of your position: that the Constitution's Office under the United States-language reaches the presidency? ${ }^{67}$

\section{Puzzle 6. Is "Officer of the United States" Coextensive with "Office under the United States"?}

You have argued that Officer of the United States embraces only Executive Branch and Judicial Branch officers, but not members of the legislature. Moreover, you have also argued that Officer of the United States and Office under the United States are coextensive. ${ }^{68}$ This

unalterable by the [national] legislature"); see also Powell v. McCormack, 395 U.S. 486, 550 (1969) (Warren, C.J.) (holding that Congress may not add to the textually express qualifications in the Constitution for Representatives and Senators).

${ }^{66}$ See Revised Statutes of the United States Passed at the First Session of the FortyTHIRD CONGRESS, 1873-'74, §1788 (Washington, Government Printing Office 2d ed. 1878) ("Every officer of the United States concerned in the disbursement of revenues thereof who carries on any trade or business in the funds or debts of the United States, or of any State ... shall upon conviction ... be incapable of holding any office under the United States." (emphasis added)); infra notes 72-73, and accompanying text; see also DAVID A. MCKNIGHT, THE ElECTORAL SYSTEM OF THE UNITED STATES: A CRITICAL AND HISTORICAL EXPOSITION OF ITS FUNDAMENTAL PRINCIPLES IN THE CONSTITUTION, AND OF THE ACTS AND PROCEEDINGS OF THE CONGRESS ENFORCING IT 346 (Philadelphia, J.B. Lippincott \& Co. 1878) (noting that "[i]t is obvious that ... the President is not regarded 'as an officer of, or under, the United States,' but as one branch of 'the Government."' (emphasis added)).

${ }^{67}$ One of my correspondents compared Washington's accepting these foreign gifts with his taking possession of state papers at the end of his second term. The two situations are not akin. The Constitution is silent with regard to state papers; it is not silent in regard to foreign gifts. Moreover, Washington had a strong claim to "his" papers. He had a continuing (fiduciary) duty to protect confidential communications. He could have believed that he was better situated to do so than his successor (who was not a party to those communications). $C f$. Folsom v. Marsh, 9 F. Cas. 342, 347 (C.C.D. Mass. 1841) (No. 4,901) (Story, J.) (discussing confidentiality concerns in regard to the publication of former presidents' and other state papers). See generally Title to Presidential Papers, 43 Op. Att'y Gen. 11 (1974) (Saxbe, Att'y Gen.). Moreover, the first Congress granted Washington a (princely) salary, $\$ 25,000$ per year, but no (separate) funds to run his office. Funds to run the executive office of the presidency came out of his salary. See Act of Sept. 23, 1789, ch. 19, § 1, 1 Stat. 72 (setting the President's and Vice President's compensation). Here too, Washington could have fairly believed that he had a proprietary interest in "his" papers.

${ }^{68}$ See supra notes 13-14, and accompanying text. Professor Amar's intuition-that all of the Constitution's office-related phrases are coextensive-has been disputed by other prominent commentators. On one hand, some of these commentators have suggested that "Office under the United States" is broader than "officer of the United States." See, e.g., JACK MASKELL, CONG. RESEARCH SERV., R41946, QUALIFICATIONS OF MEMBERS OF CONGRESS 21 n.122 (2011) (““[A]ny Office of honor, Trust or Profit under the United States' (Art. I, § 3, cl. 7 [the Disqualification Clause]) ... might be seen to be broader than the meaning of 'civil Officer' in Article II [the 


\title{
SETH BARRETT TILLMAN \\ SIX PUZZLES FOR PROFESSOR AKHIL AMAR \\ DRAFT FOR SUBMISSION PURPOSES ONLY \\ 20/10/2013 7:19 AM
}

\begin{abstract}
Impeachment Clause] ....”); cf. Michael Ramsey, My Answers to Seth Barrett Tillman's Six Puzzles, THE ORIGINALISM BLOG (March 6, 2013, 6:48 AM), http://tinyurl.com/clcmnnm ("I would say, contra [Tillman], that the President holds an 'Office under the United States' while not being an ['] officer of the United States. ${ }^{[,] ") . ~ C o m p a r e ~ C a l a b r e s i, ~ C l o s i n g ~ S t a t e m e n t, ~ A ~ T e r m ~ o f ~ A r t ~ o r ~ t h e ~ A r t f u l ~}$ Reading of Terms?, supra note 40, at 156 ("The phrase 'any Office under the United States' is potentially broader than the phrase 'officer of the United States' ...."), with Steven G. Calabresi \& Joan L. Larsen, One Person, One Office: Separation of Powers or Separation of Personnel?, 79 CORNELl L. REV. 1045, 1063 (1994) ("The sentence structure [of the Incompatibility Clause], beginning with the key words 'no person' and moving on to the phrase 'holding any Office under the United States,' clearly indicates that 'Officers of the United States' are the suspect bad apples here."), and Steven G. Calabresi \& Saikrishna B. Prakash, The President's Power to Execute the Laws, 104 YALE L.J. 541, 582 n.157 (1994) ("This 'no one else' most emphatically includes the Congress, whose members are actually precluded elsewhere in the text of the Constitution from being able to serve as '[o]fficers of the United States." (citing the Incompatibility Clause and its "office under the United States" language)).
\end{abstract}

On the other hand, Vasan Kesavan has suggested just the opposite: that "officer of the United States" is broader than "Office under the United States." See, e.g., Vasan Kesavan, The Very Faithless Elector?, 104 W. VA. L. REV. 123, 129 n.28 (2001) ("The textual argument is incredibly straightforward: A 'Person holding an Office of Trust or Profit under the United States' holds an 'Office... under the United States' and is therefore an 'Officer of the United States." (emphasis added)).

Other commentators disagree with Professor Amar's intuition, but they do not take a specific stand in regard to which category is broader. See, e.g., BRIAn C. KALt, Constitutional CliFFHANGERS: A LEGAL GUIDE FOR PRESIDENTS AND THEIR ENEMIES 89 n.16 (2012) (noting the position that "a good case [can be made] that officers 'under the authority of the United States' are not the same set as officers 'under' or 'of' the United States, and that people should be careful about treating these different phrasings as though they are necessarily identical"); JETHRO K. LIEBERMAN, A PRACTICAL COMPANION TO THE CONSTITUTION: HOW THE SUPREME COURT HAS RULED ON ISSUES FROM ABORTION TO ZONING 332 (1999) ("For the purposes of the EMOLUMENTS CLAUSE the term 'office' may mean something different from the term when used in connection with the APPOINTMENT AND REMOVAL POWER of the president or the impeachment power of Congress."); David P. Currie, The Constitution in Congress: The Second Congress, 1791-1793, 90 Nw. U. L. REV. 606, 624-25 (1996) ("Thus, it is difficult to say that the Constitution adopts a single meaning of the term 'office' or 'officer'; each clause employing these terms must be interpreted according to its own context, history, and purpose."); Gerald S. Schatz, Note, Federal Advisory Committees, Foreign Conflicts of Interest, the Constitution, and Dr. Franklin's Snuff Box, 2 D.C. L. REV. 141, 157-58 (1993) ("The obvious distinction between 'Office' and 'Office of Profit or Trust' implies strongly that the framers did not intend to bring all U.S. Government employment within the [Foreign Emolument] [C]lause's coverage.").

Additionally, the Office of Legal Counsel has suggested, on occasion, that "Office under the United States" is broader than "officer of the United States." See, e.g., Authority of Foreign Law Enforcement Agents to Carry Weapons in the United States, 12 Op. Off. Legal Counsel 67, 68, 1988 WL 391002, at*2, 1988 OLC LEXIS 41, at*5 (Apr. 12, 1988) (McGinnis, Dep'y Asst. Att'y Gen.) ("The [Foreign] Emoluments Clause must be read broadly in order to fulfill that purpose. Accordingly, the Clause applies to all persons holding an office of profit or trust under the United States, and not merely to that smaller group of persons who are deemed to be 'officers of the United States' for purposes of Article II, Section 2 of the Constitution." (emphasis added) (citing 1986 Opinion, infra)); Application of the [Foreign] Emoluments Clause to Part-Time Consultant for the 


\section{SETH BARRETT TILLMAN \\ SIX PUZZLES FOR PROFESSOR AKHIL AMAR DRAFT FOR SUBMISSION PURPOSES ONLY \\ 20/10/2013 7:19 AM}

latter position is plainly atextual, and is also inconsistent with your own writings on methodology. ${ }^{69}$ Where different terminology is employed, an inference ${ }^{70}$ (or a presumption ${ }^{71}$ ) arises that a different meaning was intended and understood. And, this inference is particularly strong where terminology within a legal instrument varies within a single sentence $^{72}-$ just as it does in Article I, Section 6, Clause $2 .{ }^{73}$

Nuclear Regulatory Commission, 10 Op. Off. Legal Counsel 96, 98, 1986 WL 213241, at *2, 1986 OLC LEXIS 66, at *5 (June 3, 1986) (Cooper, Asst. Att'y Gen.) ("Prior opinions of this Office have assumed without discussion that the persons covered by the [Foreign] Emoluments Clause were 'officers of the United States' in the sense used in the Appointments Clause, U.S. Const. art. II, § 2, cl. 2. Nevertheless, in [the] 1982 [Opinion, infra], we did advise that a person may hold an 'office of profit or trust' under the [Foreign] Emoluments Clause without necessarily being an 'officer of the United States' for purposes of the Appointments Clause." (footnote omitted)); Application of the [Foreign] Emoluments Clause of the Constitution and the Foreign Gifts and Decorations Act, 6 Op. Off. Legal Counsel 156, 157, 1982 WL 170682, at *2, 1982 OLC LEXIS 46, at*4-5 (Feb. 24, 1982) (Shanks, Dep'y Asst. Att'y Gen.) (affirming that different "language" relating to office in different constitutional clauses relates to different "purpose[s]").

${ }^{69}$ Compare Amar \& Amar, supra note 2, at 114-15 ("As a textual matter, each of these five [!] formulations seemingly describes the same stations (apart from the civil/military distinction) - the modifying terms 'of,' 'under,' and 'under the Authority of' are essentially synonymous." (emphasis added)), with Amar, A Neo-Federalist View of Article III, supra note 38, at 242 \& n.121 ("Where possible, each word of the Constitution is to be given meaning; no words are to be ignored as mere surplusage." (citing Martin v. Hunter's Lessee, 14 U.S. (1 Wheat.) 304, 334 (1816) ("It is hardly to be presumed that the variation in the language could have been accidental."); Marbury v. Madison, 5 U.S. (1 Cranch) 137, 174 (1803) ("It cannot be presumed that any clause in the constitution is intended to be without effect; and therefore such a construction is inadmissible, unless the words require it."))). Did not you, on at least one occasion, distinguish of from under as used in the Constitution's text? See, e.g., Akhil Reed Amar, Reply, Article III and the Judiciary Act of 1789: Reports of My Death are Greatly Exaggerated, 138 U. PA. L. REV. 1651, 1652 (1990) ("The two-tier thesis pays careful attention to many of [A]rticle III's words and phrases - 'judicial power,' 'of the United States,' 'vested,' 'judges,' 'arising under,' 'admiralty and maritime' and so on...." (emphasis added)).

${ }^{70}$ See Akhil Reed Amar, The Two-Tiered Structure of the Judiciary Act of 1789, 138 U. PA. L. REV. 1499, 1501 (1990) ("From this difference of phraseology, perhaps, a difference of constitutional intention may, with propriety, be inferred." (quoting Justice Story's opinion in Hunter's Lessee approvingly)).

${ }^{71}$ See Akhil Reed Amar, Intratextualism, 112 HARV. L. REV. 747, 761 (1999) (“[T] he same (or very similar) words in the same document should, at least presumptively, be construed in the same (or a very similar) way. But the flip side of the intratextual coin is that when two (or more) clauses feature different wording, this difference may also be a clue to meaning, and invite different construction of the different words." (emphasis added));

${ }^{72}$ See Saikrishna Prakash, Our Three Commerce Clauses and the Presumption of Intrasentence Uniformity, 55 ARK. L. REV. 1149, 1159-65 (2003); id. at 1172 ("It is far better to use two different words in a sentence when we mean to convey two different meanings."). One federal statute appears to have varied its office-related terminology within a single sentence. See, e.g., REVISED STATUTES OF THE UNITED STATES PASSED, supra note 66, § 1788. The lack of uniform terminology in this statute suggests that different meanings were intended.

${ }^{73}$ Compare, e.g., U.S. CONST. art. I, § 6, cl. 2 ("No Senator or Representative shall, during the Time for which he was elected, be appointed to any civil Office under the Authority of the United States, which shall have been created, or the Emoluments whereof shall have been increased during such time; and no Person holding any Office under the United States, shall be a Member of either 


\section{SETH BARRETT TILLMAN \\ SIX PUZZLES FOR PROFESSOR AKHIL AMAR \\ DRAFT FOR SUBMISSION PURPOSES ONLY \\ 20/10/2013 7:19 AM}

Moreover, structurally, the position that the two phrases are coextensive seems problematic. The Secretary of the Senate and Clerk of the House are not appointed by the President, and they do not receive presidential commissions under the Commissions Clause. Plainly, they are not Officers of the United States. But, there are two good reasons to believe that each holds an Office under the United States. Why?

First, there is (again) Hamilton's list. The Senate issued an order directing the Secretary of the Treasury to compile a report listing "every person holding any civil office or employment under the United States" "74 with their salaries. Hamilton's response included: the Secretary of the Senate and his staff, and the Clerk of the House and his staff. ${ }^{75}$ This would seem to establish that although a position might not be an office of the United States, it might be an Office under the United States. And, of course, this understanding flows from the Constitution's plain text: sometimes using Officer of the United States-language, but other times using the Office under the United States-language.

Second, the Elector Incompatibility Clause states: "[N]o Senator or Representative, or Person holding an Office of Trust or Profit under the United States, shall be appointed an Elector."76 If your view were correct, the position of elector - although it cannot be filled by a member of Congress - could be held by a non-member, non-presiding legislative officer, i.e., the Secretary of the Senate, Clerk of the House, door-keeper, sergeant-at-arms, etc. Structurally, that is a truly terrible result. What could be worse? Senators and representatives must take an Article VI oath (or affirmation). ${ }^{77}$ But the Article VI oath does not reach non-member legislative officers. ${ }^{78}$

House during his Continuance in Office." (italics and underscores added)), and Geneviève Cartier, Procedural Fairness in Legislative Functions: The End of Judicial Abstinence?, 53 U. TORONTO L.J. 217, 223 (2003) ("[Chief Justice Laskin] insisted [!] on the fact that the common law makes a distinction between offices held under the Crown and offices held under the authority of a Board created by statute...." (italics and underscores added) (citing Nicholson v. HaldimandNorfolk Regional Bd. of Comm'rs of Police, [1979] 1 S.C.R. 311, 319-20, 324 (Can.) (Laskin, C.J.))), with Saikrishna Bangalore Prakash, Response, Why the Incompatibility Clause Applies to the Office of President, 4 DuKE J. CONST. L. \& PUB. POL'Y 143, 148 (2009) ("Because the President occupies an office created under the authority of the United States, he occupies an 'Office under the United States." (italics and underscores added)). Is Professor Prakash's position in the Duke Journal of Constitutional Law \& Public Policy consistent with his prior statement in Arkansas Law Review. See supra note 72 (quoting Professor Prakash).

${ }^{74}$ See supra note 59 (quoting Senate order).

${ }^{75}$ See supra note 60 (quoting Hamilton's response to the Senate's order). Hamilton gives the Secretary of the Senate and Clerk of the House pride of place: each is listed as the head of a group or department. This indicates that (at least) the Secretary and Clerk hold Offices under the United States, and those below them may be categorized as either: (i) officers under the United States or (ii) employees under the United States.

${ }^{76}$ U.S. CONST. art. II, § 1, cl. 2 (emphasis added).

${ }^{77}$ U.S. CONST. art. VI, cl. 3 ("The Senators and Representatives before mentioned, and the Members of the several State Legislatures, and all executive and judicial Officers, both of the United States and of the several States, shall be bound by Oath or Affirmation, to support this Constitution ....").

${ }^{78}$ Id.; Steven G. Calabresi, Response, The Political Question of Presidential Succession, 48 STAN. L. REV. 155, 162 (1995) ("No constitutional oath is required of legislative officers, like the Clerk of the 


\section{SETH BARRETT TILLMAN \\ SIX PUZZLES FOR PROFESSOR AKHIL AMAR DRAFT FOR SUBMISSION PURPOSES ONLY 20/10/2013 7:19 AM}

Likewise, all such (high level) congressional staff lack independence: they can be dominated by the presiding member of their chamber (if the presiding member has a removal power) or by the factional majority of their chamber (which always has a removal power ${ }^{79}$ ). If the goal of the Elector Incompatibility Clause was to keep members of Congress from participating in the Electoral College process, ${ }^{80}$ then it hardly makes sense to preclude members from serving as electors, but to allow their dependent appointees to do so. Indeed, it is far worse to have the Clerk than the Speaker serve in the Electoral College. The Speaker is (arguably) independent, subject to election (by the voters and by the House), and faces substantial transparency expectations in regard to his official conduct. Not so the Clerk. In short, your view - that Officer of the United States is coextensive with Office under the United States - is at odds with the Constitution's plain text and it does not harmonize with the Constitution's "global structure." ${ }^{\prime 1}$ The better view is that Office under the United States is a superset of Officer of the United States. Non-member, non-presiding legislative officers are encompassed by the former category, even if not in the latter category.

Do you still maintain that Office under the United States is coextensive with Officer of the United States?

Sincerely,

House or the Secretary of the Senate ...."); cf. AMAR, BIOGRAPHY, supra note 6, at 301 ("The final paragraph of Article VI obliged a host of [Tillman adding — not all] state and federal policymakers to take personal oaths of allegiance "to support this Constitution." (emphasis added)). Compare AMAR, UNWRITTEN, supra note 6, at 421 ("Article VI obliged every important state or federal official to take an oath to support the federal Constitution ...."), with AMAR, UNWRITTEN, supra note 6, at 74-75 (explaining that the proscription against religious tests in the Article VI Religious Test Clause applies to every "federal public servant"). Professor Amar provides no explanation for why the Framers put forward language reaching every federal public servant in the Religious Test Clause, but the neighboring Oaths and Affirmations Clause only reached "important" federal officials. It is a puzzle. Actually, it is two puzzles. The first puzzle is why did the Framers entertain the distinction between the Religious Test Clause and the Oaths and Affirmations Clause, with the former reaching all federal positions, but the latter reaching only a subset of all federal positions. The second puzzle is why Professor Amar - who is obviously aware of the dichotomy - fails to discuss it. If this is not worth discussion, what is?

${ }^{79}$ See U.S. CONST. art. I, § 2, cl. 5 ("The House of Representatives shall ch[oo]se their Speaker and other Officers ...."); id. at art. I, § 3, cl. 5 ("The Senate shall chuse their other Officers, and also a President pro tempore, in the Absence of the Vice President, or when he shall exercise the Office of President of the United States."); id. at art. I, § 5, cl. 2 ("Each House may determine the Rules of its Proceedings ....”). To be clear, in my discussion in the main text, I am leaving aside complexities arising in connection with the filibuster and the entrenchment of chamber rules. The effect of such entrenchment may be to insulate congressional officers from removal by simple majority rule.

${ }^{80}$ See AMAR, BIOGRAPHY, supra note 6, at 143 ("If, however, a president were allowed to stand for reelection, he needed to be allowed to make his case to a body of electors independent of Congress." (emphasis added)); Akhil Reed Amar, A Constitutional Accident Waiting to Happen, 12 CONST. CoMM. 143, 143 (1995) ("The Framers emphatically did not want a President dependent on the legislature ...." (emphasis added)).

${ }^{81}$ Amar, supra note 8, at 1660 ("In order to really understand the [presidential succession] issue you need to have a global structural account of the Constitution." (emphasis added)). 
Seth Barrett Tillman

cc: Vikram David Amar ${ }^{82}$

${ }^{82}$ See Amar \& Amar, supra note 2 passim. A response or responses from Professor Vikram Amar would be equally welcomed. 


\section{SETH BARRETT TILLMAN \\ SIX PUZZLES FOR PROFESSOR AKHIL AMAR DRAFT FOR SUBMISSION PURPOSES ONLY 20/10/2013 7:19 AM}

\section{AUTHOR'S PROPOSED ANSWER KEY: \\ Puzzle 1. Does “Officer," as used in the Succession Clause, Encompass Legislative Officers?}

As posed, the question is "what is your current position?" Only you can know the answer to this question. My own view is that legislative officer succession is constitutional (even if unwise as a policy matter).

Text and History. The arguments marshaled against legislative officer succession are uniformly inconsistent with the Constitution's text and history contemporaneous with ratification. Moreover, these arguments frequently engage in hyperbole, ${ }^{83}$ misquote,${ }^{84}$ and mischaracterize ${ }^{85}$ early American materials.

\footnotetext{
${ }^{83}$ Hyperbole. Examples of hyperbole are plentiful. See, e.g., Akhil Reed Amar, Presidents Without Mandates (with Special Emphasis on Ohio), 67 U. CIN. L. REV. 375, 385 (1999) ("Vik Amar and I have offered a detailed analysis of why Madison was absolutely right [in regard to the unconstitutionality of legislative officers succession]..." (emphasis added)); Amar \& Amar, supra note 2, at 117 n.25 ("Later, in the First Congress, Elbridge Gerry implausibly claimed that state officers were indeed eligible to succeed, 2 ANNALS OF CONG. 1913 (Jan. 13, 1791), and in the Second Congress, Gerry voted for legislative succession, 3 ANNALS OF CONG. 302-03 (Jan. 2, 1792). Madison and several other Philadelphia Framers took a quite different position." (emphasis added)). The identity of these "several other Philadelphia Framers" who spoke to state officer eligibility is not put forward. See, e.g., Amar \& Amar, supra note 2, at 117 n.26 ("Historically, we must remember that some of the most prominent proponents of legislative eligibility also believed in state officer eligibility."). Other than Gerry, who were these purported "prominent proponents of legislative eligibility [who] also believed in state officer eligibility"? You do not identify them, nor are they identified in the sources you cite. Like you, Professor Ruth C. Silva seeks to undercut Gerry as a reliable founding era source. Silva states: "Gerry was absent from the Convention on August 6, 1787, when the [S] uccession [C]lause was discussed ...." Silva, supra note 31, at 451, 458 n.30. But there was no such debate on August 6, 1787. So what are we to make of Silva's claim, and of Professor Amar's publications which "build" on Silva's prior works? See Akhil Reed Amar, Response, Continuing the Conversation, 33 U. RICH. L. REV. 579, 584 n.37 (1999) ("My analysis of presidential succession issues builds on the work of Ruth Silva ....").
}

On another occasion, you wrote: "In fact, no less an authority than James Madison insisted that the constitutionally mandated separation of executive and legislative powers made congressional leaders ineligible [to succeed to the presidency]." Amar, supra note 5, at 27 (emphasis added). First, if Madison intended to "insist" on this argument, why do we lack any record of his putting this argument forward in House floor debate in connection with the first presidential succession statute (or any other statute)? See Act of Mar. 1, 1792, 1 Stat. 239 (repealed 1886). Second, if Madison had been committed to the proposition that the Act was unconstitutional, then why did he not seek a presidential veto and communicate his objections to President Washington and his cabinet? See ROBERT F. JONES, GEORGE WASHINGTON: ORDINARY MAN, EXTRAORDINARY LEADER 116 (2002) ("Washington did not confine himself to his official advisors; rather, he canvassed widely .... [Congressman] Madison acted as a kind of informal counsellor to the president to an extent not generally realized."). Why is your only record of Madison's (purported) position in his private correspondence with Pendleton? And, finally, if Madison was "insisting" on this position, why does Madison preface his argument modest language in the passive voice: "The objections to... [legislative officer succession in the 1792 Act] are various... It may be questioned whether these [legislative officers] are officers, in the constitutional sense." Letter from James Madison to Edmund Pendleton (Feb. 21, 1792), in 14 THE PAPERS OF JAMES MADISON 235, 236 (Robert A. Rutland et al. 


\section{SETH BARRETT TILLMAN \\ SIX PUZZLES FOR PROFESSOR AKHIL AMAR DRAFT FOR SUBMISSION PURPOSES ONLY \\ 20/10/2013 7:19 AM}

eds., 1983) (emphasis added, emphasis in the original omitted). Is it not much more likely that Madison was not "insisting" on this position? Rather, Madison was reporting to Pendleton in regard to debate on the House floor put forward by other members. And if so, Madison was not "insisting" on this position because this position was not Madison's. But see Akhil Reed Amar, Why Speakers of the House Should Never Be President, THE NEW REPUBLIC (Jan. 12, 2012, 12:00 AM), http://tinyurl.com/c461m32 (asserting that "[o]ver the constitutional objections of James Madison, Congress finessed the feud by (surprise, surprise) favoring itself: Congressional chieftains, not cabinet secretaries, topped the 1792 succession list."). How can you assert that Congress acted over Madison's objections if Madison never voiced those objections in Congress, or to any congressmen, or, in fact, to anyone prior to termination of debate on the 1792 Presidential Succession Act?

You characterize Congress as "favoring itself" by having put its leaders in the line of succession in the 1792 Presidential Succession Act. Id. Your characterization here seems inconsistent with how you characterize other early congressional material. For example, in regard to the Blount case, you note that the Senate sought to take Senators out of the scope of impeachment processes (leaving Senators subject only to unicameral expulsion proceedings, but not to House impeachment and Senate trial and disqualification proceedings). See U.S. ConsT. art. I, § 5, cl. 2 ("Each House may determine the Rules of its Proceedings, punish its Members for disorderly Behaviour, and, with the Concurrence of two thirds, expel a Member."). In regard to the Senate's Blount proceedings, your position is that the Senators acted correctly: you never suggest that their decision was infected by self-interest, selfdealing, or bias. See, e.g., Amar \& Amar, supra note 2, at 115 ("In the William Blount impeachment case in 1798, the Senate correctly rejected the idea that its members were 'civil Officers' within the meaning of the Constitution ...." (emphasis added)). Why not? Surely, a decision by Senators to take themselves out of the scope of impeachment processes affects each and every individual member's personal interests and political future. See, e.g., Brian C. Kalt, The Constitutional Case for the Impeachability of Former Federal Officials: An Analysis of the Law, History, and Practice of Late Impeachment, 6 TEX. REV. L. \& POL. 13, 107 (2001) ("[T] he Senate's decision (notably, against the House's conclusion [that Senators could be impeached]), while constitutionally defensible, shows a sort of self-interest that would not necessarily duplicate itself in the impeachment of a former executive or judicial officer." (emphasis added)). By contrast, putting the House and Senate leaders in the line of succession is - except with regard to the leaders themselves - at most self-interest once removed. Indeed, in regard to those Senators not aligned with the majority faction, their putting congressional leaders in the line of succession is against their self-interest.

${ }^{84}$ Misquote. See, e.g., Amar \& Amar, supra note 2, at 115 (dropping the ellipses and misquoting James Iredell as stating: "[W]ho ever heard of impeaching a member of the legislature?" when, in fact, Iredell stated: "[W]ho ever heard of impeaching a member of the legislature for any legislative misconduct?" (emphasis added) (quoting 4 THE DEBATES IN THE SEVERAl State CONVENTIONS, ON THE AdOPTION OF THE FEDERAL Constitution, As RECOMMENDED BY THE GENERAL CONVENTION AT PHILADELPHIA, IN 1787, at 127 (Jonathan Elliot ed., Washington, no publisher 1836))); see also, e.g., AMAR, BIOGRAPHY, supra note 6, at 172 \& n.109 ("Madison buttressed this argument [against legislative officer succession] by stressing Article II's slightly stilted syntax, which authorized Congress to declare 'what Officer,' as opposed to 'which Officer' ...." (underscores added, emphasis in the original) (quoting Letter from James Madison to Edmund Pendleton (Feb. 21, 1792), in 14 THE PAPERS OF JAMES MADISON, supra note 83, at 236)). You put forward no evidence to suggest that the use of "what" as a relative pronoun in the eighteenth century was viewed by Madison or by any of his contemporaries as "stilted." AMAR, BIOGRAPHY, supra note 6, at 172 \& n.109. The use of "what" as a relative pronoun was once popular. See, e.g., JOHN DICKINSON, AN ESSAY ON THE CONSTITUTIONAL POWER OF GREAT-BRITAIN OVER THE COLONIES IN AMERICA 391 n. (Philadelphia 1774) (“Every man's children being by nature as free as himself . . may . . . choose what society they will join themselves to ... [and] what commonwealth they will put themselves under...." (emphasis added) (quoting 


\section{SETH BARRETT TILLMAN \\ SIX PUZZLES FOR PROFESSOR AKHIL AMAR DRAFT FOR SUBMISSION PURPOSES ONLY 20/10/2013 7:19 AM}

Constitutional Structure. Likewise, the purported "structural" arguments against legislative officer succession do not inspire confidence. ${ }^{86}$ For example, you have expressly objected to legislative officer succession because such an officer, while acting as President, would not be subject to impeachment. ${ }^{87}$ But, under the plain text of the Succession Clause, Congress may put federal military officers in the line of succession. And, military officers are not subject to impeachment. ${ }^{88}$

John Locke)). And, such usage continues into our own time on both sides of the Atlantic pond. See, e.g., Campus Oil Ltd v. Minister for Indus. \& Energy (No. 2), 1983 IESC 2, [9], 1983 I.R. 88 (Ir. S.C.) (O'Higgins, CJ) ("Interlocutory relief is granted to an applicant where what he complains of is continuing and is causing him harm or injury which may be irreparable ...." (emphasis added)); $c f$., e.g., AMAR, BIOGRAPHY, supra note 6, at 236 ("In the Article III vesting clause and roster, 'shall' and 'all' meant what they said." (emphasis added)).

Furthermore, you have manipulated Madison's statement. In your text, you report Madison writing "what Officer." AMAR, BIOGRAPHY, supra note 6, at 172. In fact, he wrote "what officers." Letter from Madison to Pendleton (Feb. 21, 1792), in 14 THE PAPERS OF JAMES MADISON, supra note 83, at 236 (emphasis in the original); AMAR, BIOGRAPHY, supra note 6, at 556$57 \mathrm{n} .109$ (acknowledging - in a footnote - that Madison wrote "what officers," without indicating how the main text differs from the original). If you are unwilling to suggest that Madison's use of officers was stressed and stilted, it is hardly clear why one should conclude that his use of what was stressed and stilted. Both what and Officers were emphasized in precisely the same way.

${ }^{85}$ Mischaracterize. See supra note 6 (discussing confusion surrounding the question of whether the Framers' Constitution rejected the Westminster model of responsible government).

${ }^{86}$ Amar \& Amar, supra note 2, at 114 ("Our most important reasoning is structural: If legislators are in line to fill a vacant Oval Office, a pervasive conflict of interest will warp their judicial roles in presidential and vice-presidential impeachment proceedings...." (emphasis added)). So is your position that the Constitution prohibits legislative officer succession because it "warps" the impeachment process, but the Constitution permits Congress to put federal military officers in the line of succession, although Congress has no power at all, not even a "warped" power, to impeach military officers? How is your constitutional vision structurally coherent? See supra notes 1 (Succession Clause), 9 (Impeachment Clause), infra note 88 (collecting authority on the Impeachment Clause), and accompanying text.

${ }^{87}$ Amar \& Amar, supra note 2, at 136 n.143.

${ }^{88}$ See supra note 12 (quoting Professor Amar for embracing the civil/military distinction), and accompanying text; see also supra notes 1 (Succession Clause), 9 (Impeachment Clause), 85 (discussing competing visions of the impeachment process), and accompanying text. Compare 2 STORY, supra note 33, §790 ("All officers of the United States, therefore, who hold their appointments under the national government, whether their duties are executive or judicial, in the highest or in the lowest departments of the government, with the exception of officers in the army and navy, are properly civil officers within the meaning of the constitution, and liable to impeachment."), with AMAR, BIOGRAPHY, supra note 6, at 198-99 (noting that the House could impeach the President or "any other executive or judicial 'Officer[]" (emphasis added)). But see TIMOTHY FARRAR, MANUAL OF THE CONSTITUTION OF THE United STATES OF AMERICA 436 (Boston, Little, Brown, and Company $3 \mathrm{~d}$ ed. rev. 1872) ("The general power of impeachment and trial may extend to others besides civil officers, as military or naval officers, or even persons not in office, and to other offences than those expressly requiring a judgment of removal from office ...."); Joseph Isenbergh, Impeachment and Presidential Immunity from Judicial Process, 18 YALE L. \& POL'Y REV. 53, 66 (1999) ("The Senate may [after convicting in impeachment proceedings] remove a military officer convicted of bribery, for example, but need not, and may do nothing more than reprimand or deny a 


\section{SETH BARRETT TILLMAN \\ SIX PUZZLES FOR PROFESSOR AKHIL AMAR \\ DRAFT FOR SUBMISSION PURPOSES ONLY \\ 20/10/2013 7:19 AM}

Policy. You have argued that cabinet succession is to be preferred over legislative officer succession because the former maintains party continuity. You wrote:

If Americans elect a President of one party, why should we get stuck with a President of the opposite party [under our current system of legislative officer succession]-perhaps (as in the fictional The West Wing) a sworn foe of the person we chose? Cabinet succession would avoid this oddity. ${ }^{89}$

This policy-driven argument is simply not true. Strict cabinet succession fails to preserve party continuity in the event that the incoming President and Vice President are killed (or otherwise unable to qualify for any reason) any time between the date of the general popular election until the new President's first cabinet officer is confirmed. That is just under twelve weeks, and perhaps longer if the Senate should delay acting on the President's nominations. In such a situation, the acting presidency will fall to the first cabinet officer in the line of succession from the outgoing administration. Such an officer may be part of an administration that has been thoroughly rejected at the polls (in primaries or in the general election) and/or may be affiliated with a party different from the President-elect. Moreover, if the outgoing President has removed all his cabinet officers prior to the start of the new President's administration, then cabinet succession fails to provide for any statutory successor at all! Can we agree that the absence of any bona fide successor is a poor result?

The virtue of legislative officer succession is that an extant or newly organized House or Senate can always choose a new presiding officer who could, as conditions warrant, step into the presidency. By contrast, if cabinet succession fails, its failings cannot be corrected by normal legal channels. (Generally, Congress can only act by statute, and absent a President or acting President, Congress cannot make binding legal relations affecting non-members.) In our age of asymmetric warfare, dirty nuclear bombs, and anthrax, pure cabinet succession is irresponsible. Harry Truman, our only President to launch a nuclear attack during war time on an enemy nation, understood this. Please, stop promoting legislative officer succession: someone may get "hurt." 90

\section{Puzzle 2. Does Impeachment Extend to Former “Officers"?}

Office and Officer, as used in the Constitution, extend to former office-holders. We know this because the Constitution's text tells us so. The Incompatibility Clause states: "[N]o Person holding any Office under the United States, shall be a Member of either House during his

promotion.”). Although I am not convinced, Professor Isenbergh's efforts to revive the (minority Whig) intellectual tradition regarding the Impeachment Clause is a major contribution to the academic literature.

${ }^{89}$ Amar, supra note 5, at 23 (emphasis added).

${ }^{90}$ See AMAR, UnwritTEN, supra note 6, at 405 ("Those who are serious about the American constitutional project, and who would like to see the document's text mesh with actual practice in a way that ultimately strengthens both text and practice, should strive to repeal and replace... [the 1947 Presidential Succession] statute before anyone gets hurt." (emphasis added)); Akhil Reed Amar, Presidents, Vice Presidents, and Death: Closing the Constitution's Succession Gap, 48 ARK. L. REV. 215, 222 (1995) ("There is, in short, a time bomb ticking away in our Constitution, and the time to defuse it is now, before anyone gets hurt." (emphasis added)). 


\section{SETH BARRETT TILLMAN \\ SIX PUZZLES FOR PROFESSOR AKHIL AMAR DRAFT FOR SUBMISSION PURPOSES ONLY \\ 20/10/2013 7:19 AM}

Continuance in Office." 91 The constitutional default is that Office-language extends to former office-holders. If that were not the default, then this clause's "during his continuance in office" language would be wholly without function. It is precisely to turn that default "off" that this language had to be included.

By contrast, the Ineligibility Clause states: "No Senator or Representative shall, during the Time for which he was elected, be appointed to any civil Office under the Authority of the United States, which shall have been created, or the Emoluments whereof shall have been [i]ncreased during such time." 92 Here, the default has not been turned "off," and, as a result, the default interpretive rule applies. That is why notwithstanding a Senator's resigning, he or she remains ineligible for appointment during the remainder of the term for which he or she had been elected. Obviously, this clause extends to former "Senators" and former "Representatives" even though textually it speaks only to "Senators" and "Representatives." The latter language (i.e., "Senators" and "Representatives," which appears in the text of the Ineligibility Clause) encompasses the prior language (i.e., "former Senators" and "former Representatives") precisely because the constitutional default has not been turned "off."93

\footnotetext{
${ }^{91}$ U.S. CONST. art. I, § 6, cl. 2 (Incompatibility Clause) (emphasis added).

${ }^{92} I d$. (Ineligibility Clause) (emphasis added).

${ }^{93}$ Albeit, in certain circumstances, the constitutional default might be "off" because the contemporaneous understanding of good conduct by former fiduciaries would not extend to the factual situation under consideration. In other words, whether a particular constitutional proscription extends to a former officer depends both on the factual context and on the particular nature of the proscription at hand. If a constitutional provision proscribes behavior that a reasonable person circa 1789 would have applied to a former fiduciary, then the provision applies. Otherwise not. No doubt this will seem to some like some sort of modern balancing test. Not so. This result is mandated by the Constitution's express text. See U.S. CONST. art. III, §3, cl. 1 ("The judicial Power shall extend to all Cases, in Law and Equity, arising under this Constitution ...." (emphasis added)). What is equity? It is the law governing the conduct of fiduciaries. See Paul D. Finn, The Forgotten "Trust": The People and the State, in EQUITY: IssuES AND TRENDS 131, 133 (Malcolm Cope ed., 1995) (noting that English judges brought public officials "into a fiduciary relationship with the public" (citing R v. Bembridge, (1783) 99 Eng. Rep. 679 (K.B.) (Lord Mansfield, CJ))). See generally R v. Boston (1923) 33 CLR 386, 412 (Austl.) (Higgins, J) ("He is a member of Parliament, holding a fiduciary relation towards the public, and that is enough.”); Robert French, Chief Justice of the High Court of Australia, Seventh Annual St Thomas More Forum Lecture: Public Office and Public Trust (Canberra June 22, 2011), available at http://tinyurl.com/ch8bd6t.
}

Interestingly, American practitioners and academics have independently arrived at conclusions which are very similar to their Australian counterparts. See, e.g., Memorandum for William P. Marshall, Deputy Counsel to the President, from Randolph D. Moss, Assistant Attorney General, Office of Legal Counsel, Re: Application of the Coreligionists Exemption in Title VII of the Civil Rights Act, at $* 22$ n.46 (Oct. 12, 2000) (noting that "[t]here is virtually no federal case law discussing what constitutes a 'public trust' for purposes of [A]rticle VI's religious test ban," and hypothesizing that it extends either to "Senators and Representatives" and/or to "any position or function the performance of which is subject to a duty of loyalty to the United States" (emphasis added)), available at http://works.bepress.com/seth_barrett_tillman/164/; Geoffrey P. Miller, The Corporate Law Background of the Necessary and Proper Clause, in THE ORIGINS OF THE NECESSARY AND PROPER Clause 144 (Gary Lawson et al. eds., 2010); Mary Sarah Bilder, The Corporate Origins of Judicial Review, 116 Yale L.J. 502 (2006); Evan J. Criddle, Fiduciary Foundations of Administrative Law, 54 UCLA L. REV. 117 (2006); Eric Enlow, The Corporate Conception of the State and the Origins of 


\section{SETH BARRETT TILLMAN \\ SIX PUZZLES FOR PROFESSOR AKHIL AMAR \\ DRAFT FOR SUBMISSION PURPOSES ONLY \\ 20/10/2013 7:19 AM}

I suppose you could argue that the "during his continuance in office" language in the Incompatibility Clause was "redundant," and it functioned merely as "clarifying"94 language. But, how does that work? If the constitutional default is, as you suggest, that former officers are merely private citizens (i.e., the Succession Clause's office-language does not extend to former officers), then it is the Ineligibility Clause (not the Incompatibility Clause) which is in dire need of clarifying language (i.e., language indicating that the force of the clause extends to former Representatives and former Senators). Yet, the Ineligibility Clause lacks any hint of such language.

\section{Puzzle 3. Who are the "Officers of the United States"?}

Delegates to an Article V national convention are not "Officers of the United States." Like members of Congress and federal electors, Article V convention delegates sit at the apex of authority within their federal institution. Because they are not subject to direction or supervision (e.g., under the President, or a department head, or some judicial authority, or by anyone else for that matter) in the normal course of their (discretionary) duties, they are better characterized as holders of a "public trust under the United States" per Article VI. ${ }^{95}$ In short, Article V convention members are neither (i) Officers nor (ii) Officers of or under the United States.

\section{Puzzle 4. Is the President an "Officer of the United States"?}

In popular nomenclature, the President is an "Officer of the United States." But, that is not how the Constitution uses this phrase. "Officer of the United States" is a term of art which is lexicographically defined by the Constitution. See United States v. Mouat, 124 U.S. 303, 307 (1888) (Miller, J.) ("Unless a person in the service of the Government, therefore, holds his place by virtue of an appointment by the President, or of one of the courts of justice or heads of Departments authorized by law to make such an appointment, he is not strictly speaking, an officer of the United States." (emphasis added)). Officer of the United States is a term of art which refers to positions subject to the Appointments Clause, the Inferior Officer Appointments Clause, and (arguably) the Recess Appointments Clause. ${ }^{97}$ Hence, the

Limited Constitutional Government, 6 WASH. U. J.L. \& POL'Y 1 (2001); Robert G. Natelson, The Agency Law Origins of the Necessary and Proper Clause, 55 CASE W. RES. L. REV. 243 (2004); Robert G. Natelson, The Constitution and the Public Trust, 52 BUFF. L. REV. 1077 (2004).

${ }^{94}$ See Akhil Reed Amar, Constitutional Redundancies and Clarifying Language, 33 VAL. U. L. REV. 1 (1998).

${ }^{95}$ U.S. CONST. art. VI ("[N]o religious Test shall ever be required as a Qualification to any Office or public Trust under the United States." (emphasis added)); see also supra note 15 (discussing the scope of the Constitution's public trust under the United States-language).

${ }^{96}$ See Amar, supra note 71, at 791 ("Legal words and phrases can sometimes be used as terms of art, with nuances of meaning not well captured by standard dictionaries reflecting lay usage. Often we seek the meaning of a word cluster - a phrase - rather than of a single word, but ordinary dictionaries typically feature discrete entries for individual words." (emphasis added)).

${ }^{97}$ See SILVA, supra note 31, at 149 ("[T] he only election by presidential electors known in the Constitution is the election of a President and a Vice President. 'Officers of the United States' are not appointed by electoral colleges. They are appointed by the President and Senate, by the President 


\section{SETH BARRETT TILLMAN \\ SIX PUZZLES FOR PROFESSOR AKHIL AMAR DRAFT FOR SUBMISSION PURPOSES ONLY \\ 20/10/2013 7:19 AM}

President of the United States is not an Officer of the United States, notwithstanding the fact that the Constitution, in various clauses, describes the presidency in the more generic language of Office. ${ }^{98}$

\section{Puzzle 5. Is the Presidency an "Office . . under the United States"?}

Office under the United States extends to all positions created, regularized, or defeasible by federal statute. Office under the United States is a superset of Officer of the United States. ${ }^{99}$ In addition to all the positions in the latter category, the former category also includes nonpresiding, non-member officers chosen by the House under the House Officers Clause (e.g., Clerk of the House) or by the Senate under the Senate Officers Clause (e.g., Secretary of the Senate). ${ }^{100}$ Hence, the presidency is not an Office under the United States. See also answer 4, supra. Office under the United States does not reach constitutionally-created offices, or elected officials, or officials at the apex of a branch of the government (i.e., officials who are not subject to direction or supervision in the regular course of their duties ${ }^{101}$ ). Thus, Office under the United States does not encompass the President, Vice President, Senate President Pro Tempore, Speaker of the House, members of either house of Congress, federal electors, and Article $\mathrm{V}$ convention members. Again, these latter positions are better characterized as "public trust[s] under the United States" per Article VI's Religious Test Clause.

alone, by the department heads, or by the courts of law." (emphasis added)); Silva, supra note 31, at 475 ("[T]he only election by presidential electors known in the Constitution is the election of the President and Vice President. 'Officers of the United States' are appointed by the President and the Senate, by the President alone, by the department heads, or by the courts. Officers in the constitutional sense are not elected by the electoral colleges." (emphasis added)); Amar, Response, Continuing the Conversation, supra note 83, at 584 n.37 ("My analysis of presidential succession issues builds on the work of Ruth Silva...."). Silva rejects the view that the President is an Officer of the United States. Precisely how are you building on Silva's work?

${ }^{98}$ U.S. CONST. art. II, $\S 4$ ("The President, Vice President and all civil Officers of the United States, shall be removed from Office on Impeachment for, and Conviction of, Treason, Bribery, or other high Crimes and Misdemeanors." (emphasis added)). The generic Office embraces three distinct categories: the President, Vice President, and civil Officers of the United States. It follows that although the presidency is an office, the president is not an officer of the United States.

${ }^{99}$ See infra note 15 , and accompanying text.

${ }^{100}$ See U.S. CONST. art. I, § 2, cl. 4 (applying to the House); id. art. I, § 3, cl. 3 (applying to the Senate).

${ }^{101}$ See Anne Twomey, The Constitution of New South Wales 438 (2004) ("[O]ne would assume that [an elective office] is not ... held 'under the Crown'."); id. (suggesting that an officer under the Crown is one "appointed by" or "removable by" a "representative of the Crown," and "accountable to the Crown and subject to the supervision of an officer appointed by the Crown" (citing Hodel v Cruckshank (1889) 3 QLJ 141 (Qld S.C.) (Lilley, CJ))); CARNEY, supra note 14, at 67-68 (same) (citing Hodel v Cruckshank (1889) 3 QLJ 141 (Qld S.C.) (Lilley, CJ)); see also State ex rel. Ragsdale v. Walker, 33 S.W. 813, 814 (Mo. 1896) (Macfarlane, J.) (“An office under the state must be one created by the laws of the state. The incumbent must be governed by state laws and must exercise his powers and perform his duties in obedience to a statute of the state." (emphasis added)); In re Corliss, 11 R.I. 638 (1876) (Durfee, C.J., Burges, Potter, Matteson, JJ.) ("We think, too, the office is an office 'under the United States.' It was created by act of Congress, and all its powers and duties were conferred and imposed by Congress."); supra note 51 (collecting other state case law); infra note 112 (same). 


\section{SETH BARRETT TILLMAN \\ SIX PUZZLES FOR PROFESSOR AKHIL AMAR DRAFT FOR SUBMISSION PURPOSES ONLY 20/10/2013 7:19 AM}

See answer 3, supra (discussing the Constitution's public trust under the United Stateslanguage).

This position is not idiosyncratic. Good early authority distinguished holders of "office" from holders of "public trusts." Alexander Hamilton was one such early authority; ${ }^{102}$ James Madison was a second such authority; ${ }^{103}$ and, George Washington, a third. ${ }^{104}$ Apparently, later authorities have taken little interest in the public trust-language in the Religious Test Clause. ${ }^{105}$ This unwillingness to explore the Constitution's actual text is difficult to explain.

${ }^{102}$ See THE FEDERALIST No. 70 (Alexander Hamilton), supra note 65, at 376 ("If it be a public trust or office in which they are clothed with equal dignity and authority, there is peculiar danger of personal emulation and even animosity." (emphasis added)); see also 9 STATE OF NEW YORK: MESSAGES FROM THE GOVERNORS, 1892-1898, at 515 (Charles Z. Lincoln ed., Albany, J.B. Lyon Co. 1909) (reproducing May 23, 1894 veto message of Governor Roswell P. Flower, which stated: "That one who holds the power to appoint a public officer, to remove him at will and appoint his successor, to fix his salary and to change it from time to time, holds a public trust will not be disputed ...."placing the officers below the holders of public trusts (emphasis added)); $c f$. Amar, supra note 58, at 448 ("If [Professor] Friedman finds these rule-of-law ideas underlying coextensiveness 'unfathomable,' immersion in eighteenth-century sources might help to clear up the confusion." (emphasis added)).

${ }^{103}$ Madison suggested that statutory presidential succession is "an annexation of one office or trust to another office." Letter from James Madison to Edmund Pendleton (Feb. 21, 1792), in 14 THE PAPERS OF JAMES MADISON, supra note 83, at 236 (emphasis added). See also Amar \& Amar, supra note 2 passim (discussing Madison-Pendleton letter).

${ }^{104}$ Compare, e.g., Letter from George Washington to Eléonor François Élie, Comte de Moustier (May 25, 1789), in 30 ThE Writings of GEORGE WASHINGTON 333, 334 (John C. Fitzpatrick ed., 1939) ("The impossibility that one man should be able to perform all the great business of State, I take to have been the reason for instituting the great Departments, and appointing officers therein, to assist the supreme Magistrate in discharging the duties of his trust." (emphasis added)), and BRYAN A. GARNER, A DiCTIONARY OF MODERn LEGAL USAGE 540 (2d ed. 2001) (defining "magistrate" and noting "the word ... once referred to the official first in rank in a branch of government" (citing Justice Cardozo) (emphasis added)), with AMAR, BIOGRAPHY, supra note 6, at 193 (quoting this passage from the Washington to Élie letter), and Akhil Reed Amar, Some Opinions on the Opinions Clause, 82 VA. L. REV. 647, 658-59 (1996) (same).

${ }^{105}$ See, e.g., AMAR, UNWRITTEN, supra note 6, at 74-75 ("The central meaning of the [Religious Test] [C]lause - not some [1] uncommon, [2] counterintuitive, [3] quirky, [4] peripheral application, but its basic thrust, its main objective - is that no federal public servant may ever be forced to pass a religious test."). Precisely what (or whose) "quirky" meaning did you have in mind? See, e.g., Letter from Akhil Reed Amar to Stuart Taylor Jr. (Feb. 16, 1999), in Akhil Reed Amar, On Impeaching Presidents, 28 HOFSTRA L. REV. 291, 341 (1999) ("Good articles - even 'brilliant' ones - must squarely present the counterarguments and counterevidence for their readers to see."); Letter from Akhil Reed Amar to Stuart Taylor Jr. (Feb. 8, 1999), in id. at 326 ("Many of us have studied the Constitution and its history for years - week in, week out. Can you (a great journalist) or [Professor] Joseph [Isenbergh] (a distinguished tax lawyer) claim the same?"); cf., e.g., AMAR, BIOGRAPHY, supra note 6, at 568 n.53 ("[Professor Raoul] Berger's argument [with regard to the impeachability of Senators] made a hash of constitutional text, structure, and precedent." (emphasis added)); $i d$. at $545 \mathrm{n} .45$ (denominating Berger's view as "somewhat cranky" (emphasis added)); Amar \& Amar, supra note 2, at 134 ("[Assistant Attorney General] McGregor's reasoning is - not to mince words - shoddy." (emphasis added) (footnote omitted)). It would be very helpful if Professor Amar were to explain precisely what language in the Religious Test Clause covers the Secretary of the 


\section{SETH BARRETT TILLMAN \\ SIX PUZZLES FOR PROFESSOR AKHIL AMAR \\ DRAFT FOR SUBMISSION PURPOSES ONLY \\ 20/10/2013 7:19 AM}

\section{Puzzle 6. Is "Officer of the United States" Coextensive with "Office under the United States"?}

Because the "eighteenth-century world [was] sensitive to fine gradations of formal title,"106 it would be inappropriate to assume - absent some meaningfully probative evidence - that the original public meaning of Officer of the United States was coextensive with Office under the United States. You assume the meanings of the two phrases are coextensive, but you put forward no support for your position. Your view appears to be an intuition, as opposed to a reasoned conclusion. ${ }^{107}$ The fact that members of Congress are in neither category (your position, and one which I share) does not establish that the two categories are otherwise coextensive (again, your position). Your position - that as a matter of original public meaning the President is an Officer of and under the United States - is also unsupported.

James Madison and Professor Akhil Amar. As of August 20, 1787, the draft Constitution's version of the Necessary and Proper Clause stated: "The Congress shall have Power . . . to make all laws necessary and proper for carrying into execution the foregoing powers, and all other powers vested by this Constitution, in the Government of the U.S. or any department of officer thereof." 108 Madison and Pinckney "moved to insert between 'laws' and 'necessary' 'and establish all offices'. [I]t appearing to them liable to cavil that the latter was not included in the former." 109 Madison and Pinckney's motion was opposed by Gouverneur Morris, Wilson, Rutledge, and Ellsworth; Morris and these other Framers "urged that the [proposed] amendment could not be necessary." 110 As a result, Madison's motion was defeated nine to two.

Although Madison's proposed language was not incorporated in the Constitution, we can still properly turn to his motion as evidence of then prevailing common usage. We are not looking to the Convention record as legislative history; rather, we are looking to the record as evidence of common usage, akin to a contemporaneous domestic dictionary. ${ }^{111}$

Senate and Clerk of the House. He must believe these positions are covered by some language in the clause. But what language he is relying on remains a mystery.

${ }^{106}$ AMAR, BIOGRAPHY, supra note 6, at 572 n.21.

${ }^{107}$ See supra notes 13-14, 68, and accompanying text.

${ }^{108} 2$ FARRAND's RECORDS, supra note 36 , at 344-45.

${ }^{109} \mathrm{Id}$. at 345 (emphasis added).

${ }^{110} \mathrm{Id}$.

${ }^{111}$ See Vasan Kesavan \& Michael Stokes Paulsen, The Interpretive Force of the Constitution's Secret Drafting History, 91 GEO. L.J. 1113, 1187 (2003) ("In other words, the secret drafting history may be a specialized dictionary or constitutional concordance of sorts."); see also Antonin Scalia \& John F. Manning, A Dialogue on Statutory and Constitutional Interpretation, 80 GEO. WASH. L. REV. 1610, 1616 (2012):

[Justice Scalia] And by the way, I don't object to all uses of legislative history. If you want to use it just to show that a word could bear a particular meaning-if you want to bring forward floor debate to show that a word is sometimes used in a certain sensethat's okay. I don't mind using legislative history just to show that a word could mean a certain thing. We are trying to ascertain how a reasonable person uses language, and the way legislators use language is some evidence of that, though perhaps not as persuasive 


\section{SETH BARRETT TILLMAN \\ SIX PUZZLES FOR PROFESSOR AKHIL AMAR DRAFT FOR SUBMISSION PURPOSES ONLY \\ 20/10/2013 7:19 AM}

Madison's use of the term office contradicts your position. Your position is that office is coextensive with officer of and under the United States, and the latter phrases encompass the President. But, clearly the presidency is not "established" either by Congress or by "law," that is "by statute;" 112 rather, it is established by the Constitution.

Admittedly, Madison's usage here does not square with my position either. My position is that the Constitution's prescribed language for statutory office is Office under the United States. In other words, Madison should have used Offices under the United States rather than Offices. Still, I am not particularly bothered by this inconsistency. Madison made his motion on August 20, 1787. The language of the Appointments Clause - the mechanism for appointing federal officers - remained amorphous between August 23 and September 4, 1787, and it was at this juncture that the Senate was restricted to its current advice and consent role in favor of presidential exclusivity in regard to nominating (noninferior) Officers of the United States. ${ }^{113}$ Likewise, Gouverneur Morris and the Committee of Style were not appointed until September 8, 1787; it was he and the Committee of Style which cleaned up the Constitution's use of Office and Officer. In other words, back on August 20, 1787, Madison would have had to have been a clairvoyant to choose Officerelated language consistent with the terminology which emerged after the Appointments Clause took shape and after the Committee of Style reported on September 12, 1787.

The Appointments Clause lexicographically defined the scope of Officers of the United States. It took what had been an undefined term and defined it midway through the process of negotiating the Constitution. Once Officers of the United States was defined by the Appointments Clause, all other clauses using this term (and any other Office-related language) had to be harmonized or rejiggered with the definition provided by the Appointments Clause. When the Committee of Style changed Office-related language, even absent general consent to such changes and even absent any clause-specific authorization, ${ }^{114}$

evidence as a dictionary. That is using legislative history as (mildly) informative rather than authoritative: "the word can mean this because people sometimes use it that way, as the legislative debate shows," rather than "the word must mean this because that is what the drafters said it meant."

112 See AMAR, BIOGRAPHY, supra note 6, at 170 (stating that "by Law," as used in the Succession Clause, means "by a statute presumably enacted in advance"); see also Office of Pers. Mgmt. v. Richmond, 496 U.S. 414, 424 (1990) (Kennedy, J.) ("Money may be paid out only through an appropriation made by law; in other words, the payment of money from the Treasury must be authorized by a statute." (emphasis added)); State ex rel. Watson v. Cobb, 2 Kan. 32 (1863) (Kingman, J.) ("An office in this country can only be created by law." (emphasis added)). Again, following the rule announced by the Supreme Court of Kansas, the presidency and vice presidency which are not "created by law" - are not "offices." See also supra notes 51, 101 (collecting other state case law).

${ }^{113} 2$ FARRAND's RECORDS, supra note 36, at 495; $c f$. David Jones, Note, Weiss v. United States, Military Judges and Appointment by Indirection, 16 WHITTIER L. REV. 575, 611 (1995) ("Finally, on September 4, the version of the Appointments Clause appeared in its current form.").

${ }^{114}$ See AMAR, BIOGRAPHY, supra note 6, at 170-71 (explaining that the Committee Style "shortened the [Succession] [C]lause with no apparent intention of changing its meaning"); Amar \& 


\section{SETH BARRETT TILLMAN \\ SIX PUZZLES FOR PROFESSOR AKHIL AMAR \\ DRAFT FOR SUBMISSION PURPOSES ONLY \\ 20/10/2013 7:19 AM}

it was just doing its job. The Committee of Style inherited diverse Office-related language. The Committee of Style did not leave all such Office-related language unchanged, nor did the Committee standardize this language across the Constitution. Instead, the Committee of Style kept diverse language, but amended it on a clause-by-clause basis.

In other words, when Morris changed the language of the Succession Clause from "Officer of the United States" to "Officer," he may have been attempting to make the language conform to its original [private] meaning, i.e., to what the Convention intended or agreed to in its prior debates (based on its votes). ${ }^{115}$ To do this, Morris had to amend the draft Constitution's diverse Office-language in light of the definition of Officer of the United States which took shape in the Appointments Clause. This view also explains why the Committee of Style dropped "other" from the text of the Impeachment Clause. ${ }^{116}$ Finally, this view explains why the Committee of Style changed the Religious Test Clause's any office or public trust under the Authority of the United States-language to any Office or public Trust under the United States. ${ }^{117}$ If all the Office-related language in the Constitution means the same thing, as you have argued, the Committee of Style should have left it all unchanged, or the Committee should have changed all such language to a uniform standard. But the Committee of Style rejected both of those approaches. In these circumstances, one can fairly conclude that Officer of the United States means one thing; Office under the United States, another.

\section{(continued)}

\footnotetext{
Amar, supra note 2, at 116 ("A later style committee deleted the words "of the United States," but no evidence suggests that this style change was meant to change meaning."); id. at 116 n.18 (same).

${ }^{115} I d$.

${ }^{116}$ See supra notes 32-37, and accompanying text (discussing the Impeachment Clause).

117 See PETER K. Rofes, THE RELIGION GUARANTEES: A REFERENCE GUIDE TO THE UNITED STATES CONSTITUTION 12 (2005) ("The Committee of Style rephrased the language by eliminating the words 'the authority of"').
} 
SETH BARRETT TILLMAN

SIX PUZZLES FOR PROFESSOR AKHIL AMAR

DRAFT FOR SUBMISSION PURPOSES ONLY

20/10/2013 7:19 AM

\section{BIBLIOGRAPHY OF AKHIL REED AMAR-AUTHORED MATERIALS \\ QUOTED OR CITED IN \\ SIX PUZZLES}

\section{TESTIMONY}

Ensuring the Continuity of the United States Government - The Presidency: Joint Hearing before the S. Comm. on the Judiciary and Committee on Rules and Administration, 108th Cong. 7 (2003) (statement of Akhil Reed Amar, Southmayd Professor of Law and Political Science, Yale Law School).

Presidential Succession Act: Hearing Before the Subcomm. on the Const. of the H. Comm. on the Judiciary, 108th Cong. 52 (2004) (statement of Akhil Reed Amar, Southmayd Professor of Law and Political Science, Yale Law School).

\section{BOOKS}

AKHIL REED AMAR, AMERICA’s CONSTITUTION: A BIOGRAPHY (2005).

AKHIL REED AMAR, AMERICA’s UNWRITTEN CONSTITUTION (2012).

\section{JOURNAL ARTICLES}

[1] Akhil Reed Amar, America's Constitution, Written and Unwritten, 57 SYR. L. ReV. 267 (2007).

[2] Akhil Reed Amar, Applications and Implications of the Twenty-Fifth Amendment, 47 Hous. L. REV. 1 (2010).

[3] Akhil Reed Amar, Attainder and Amendment 2: Romer's Rightness, 95 MicH. L. REV. 203 (1996).

[4] Akhil Reed Amar, Reply, Article III and the Judiciary Act of 1789: Reports of My Death are Greatly Exaggerated, 138 U. PA. L. REV. 1651 (1990).

[5] Akhil Reed Amar, The Consent of the Governed: Constitutional Amendment Outside Article V, 94 COLUM. L. REV. 457 (1994).

[6] Akhil Reed Amar, A Constitutional Accident Waiting to Happen, 12 Const. Comm. 143 (1995).

[7] Akhil Reed Amar, Constitutional Redundancies and Clarifying Language, 33 VAL. U. L. REV. 1 (1998).

[8] Akhil Reed Amar, Response, Continuing the Conversation, 33 U. RICH. L. REV. 579 (1999).

(continued) 
SETH BARRETT TILLMAN

SIX PUZZLES FOR PROFESSOR AKHIL AMAR

DRAFT FOR SUBMISSION PURPOSES ONLY

20/10/2013 7:19 AM

\section{JOURNAL ARTICLES (cont.)}

[9] Akhil Reed Amar, A Few Thoughts on Constitutionalism, Textualism, and Populism, 65 FORDHAM L. REV. 1657 (1997).

[10] Akhil Reed Amar, On Impeaching Presidents, 28 Hofstra L. ReV. 291 (1999).

[11] Akhil Reed Amar, Intratextualism, 112 HARV. L. REV. 747 (1999).

[12] Akhil Reed Amar, A Neo-Federalist View of Article III: Separating the Two Tiers of Federal Jurisdiction, 65 B.U. L. REV. 205 (1985).

[13] Akhil Reed Amar, Some Opinions on the Opinions Clause, 82 VA. L. REV. 647 (1996).

[14] Akhil Reed Amar, Philadelphia Revisited: Amending the Constitution Outside Article V, 55 U. CHI. L. REV. 1043 (1988).

[15] Akhil Reed Amar, The President, the Cabinet, and Independent Agencies, 5 U. ST. THOMAS J.L. \& PUB. POL’Y 36 (2010).

[16] Akhil Reed Amar, Presidents, Vice Presidents, and Death: Closing the Constitution's Succession Gap, 48 ARK. L. REV. 215 (1995).

[17] Akhil Reed Amar, Presidents Without Mandates (with Special Emphasis on Ohio), 67 U. CIN. L. REV. 375 (1999).

[18] Akhil Reed Amar, Marbury, Section 13, and the Original Jurisdiction of the Supreme Court, 56 U. CHI. L. REV. 443 (1989).

[19] Akhil Reed Amar, Some New World Lessons for the Old World, 58 U. CHI. L. REV. 483 (1991).

[20] Akhil Reed Amar, Of Sovereignty and Federalism, 96 YALE L.J. 1425 (1987).

[21] Akhil Reed Amar, The Supreme Court, 1999 Term - Foreword: The Document and the Doctrine, 114 HARV. L. REV. 26 (2000).

[22] Akhil Reed Amar, Taking Article III Seriously: A Reply to Professor Friedman, 85 Nw. U.L. REV. 442 (1991).

[23] Akhil Reed Amar, The Two-Tiered Structure of the Judiciary Act of 1789, 138 U. PA. L. REV. 1499 (1990).

[24] Akhil Reed Amar \& Vikram David Amar, Is the Presidential Succession Law Constitutional?, 48 STAN. L. REV. 113 (1995).

(continued) 
SETH BARRETT TILLMAN

SIX PUZZLES FOR PROFESSOR AKHIL AMAR

DRAFT FOR SUBMISSION PURPOSES ONLY

20/10/2013 7:19 AM

\section{OTHER}

Akhil Reed Amar, Why Speakers of the House Should Never Be President, THE NEW REPUBLIC (Jan. 12, 2012, 12:00 AM), http://tinyurl.com/c46lm32.

(continued) 
SETH BARRETT TILLMAN

SIX PUZZLES FOR PROFESSOR AKHIL AMAR

DRAFT FOR SUBMISSION PURPOSES ONLY

20/10/2013 7:19 AM

\section{Citations To SIX PUZZLES}

Terrence Berres, Michael Ramsey's Answers to Seth Barrett Tillman's Six Puzzles, MiLWAUKEE FEDERALISTS (March 6, 2013, 3:22 PM), http://tinyurl.com/cvynuw6.

Terrence Berres, Answers to Six Puzzles, MiLwaukeE Federalists (Feb. 22, 2013, 2:42 PM), http://tinyurl.com/b2994h7.

Terrence Berres, What's the problem, office(r)?, MiLwAUKEE FEDERALISTS (Feb. 15, 2013, 11:16 AM), http://tinyurl.com/c6f8rg7.

Chris Green, A Few Thoughts on the Tillman Puzzles, The Originalism Blog (March 7, 2013, 5:23 PM), http://tinyurl.com/ckfpppd.

Michael Ramsey, Michael Stern on Seth Barrett Tillman's Six Puzzles, The Originalism BLOG (March 11, 2013, 6:17 AM), http://tinyurl.com/dy5xhr8.

Michael Ramsey, My Answers to Seth Barrett Tillman's Six Puzzles, The Originalism Blog (March 6, 2013, 6:48 AM), http://tinyurl.com/clcmnnm.

Michael Ramsey, Seth Barrett Tillman's Answers on "Officers" and "Offices", THE ORIGINALISM BLOG (Feb. 25, 2013, 7:00 AM), http://tinyurl.com/adl38hj.

Michael Ramsey, Seth Barrett Tillman: Six Puzzles for Professor Akhil Amar, THE ORIGINALISM BLOG (Feb. 19, 2013, 7:00 AM), http://tinyurl.com/ah2oeny.

Glenn Reynolds, Offices and Officers: Six Puzzles For Professor Akhil Amar, InstaPundit (Feb. 18, 2013, 8:38 AM), http://pjmedia.com/instapundit/163624/.

Lawrence B. Solum, Tillman on Amar on "Office" \& "Officers" in the Constitution, LeGAL THEORY BLOG (Feb. 20, 2013, 3:43 PM), http://tinyurl.com/b3k9x4c.

Michael Stern, Six Answers for Six Puzzles, POINT OF ORder: A Discussion of CONGRESSIONAL LEGAL ISSUES (March 7, 2013, 7:43 AM), http://tinyurl.com/c328jsv.

Michael Stern, Tillman's Puzzles for Amar (or Who You Callin “Atextual”?), PoINT OF ORDER: A Discussion of CONGREssional LEgAL IsSUES (Feb. 22, 2013, 10:02 AM), http://tinyurl.com/ae2dwlv.

Elektra Tig, Six Answers for Seth Barrett Tillman, EleKTRATiG (March 6, 2013, 7:37 PM), http://tinyurl.com/cfpsxtq.

Elektra Tig, Six Puzzles for Professor Akhil Amar, EleKTRATig (Feb. 18, 2013, 9:55 AM), http://tinyurl.com/b9dfva2.

WORD COUNT: 19,551 